\title{
On the Role of Isothermal Martensite Formation during Cryogenic Treatment of Steels
}

Villa, M.; Somers, M. A. J.

Published in:

H T M

Link to article, DOI:

$10.3139 / 105.110420$

Publication date:

2020

Document Version

Publisher's PDF, also known as Version of record

Link back to DTU Orbit

Citation (APA):

Villa, M., \& Somers, M. A. J. (2020). On the Role of Isothermal Martensite Formation during Cryogenic Treatment of Steels. H T M, 75(5), 263-286. https://doi.org/10.3139/105.110420

\section{General rights}

Copyright and moral rights for the publications made accessible in the public portal are retained by the authors and/or other copyright owners and it is a condition of accessing publications that users recognise and abide by the legal requirements associated with these rights.

- Users may download and print one copy of any publication from the public portal for the purpose of private study or research.

- You may not further distribute the material or use it for any profit-making activity or commercial gain

- You may freely distribute the URL identifying the publication in the public portal

If you believe that this document breaches copyright please contact us providing details, and we will remove access to the work immediately and investigate your claim 


\title{
On the Role of Isothermal Martensite Formation during Cryogenic Treatment of Steels ${ }^{*}$
}

\author{
Zur Rolle der isothermen Martensitbildung bei \\ der Tieftemperaturbehandlung von Stählen
}

Abstract/Kurzfassung

This contribution addresses the effect of sub-zero Celsius treatments at cryogenic temperatures on the steel microstructure. It is shown that the formation of martensite, including the socalled isothermal, i. e. time dependent or thermally activated, martensitic product, can provide an explanation to the observations in the literature that both the temperature of cryogenic treatment and the holding time at cryogenic temperatures may have an influence on the performance of steel products in service. This review traces the most important stages in the development of cryogenic treatments along the last 95 years and describes it in parallel with the description of the current state of understanding of the kinetics of martensitic transformation in steel. In the last part of the contribution, the new insight is put into context with a practical example where various types of subzero Celsius treatments are applied.

Keywords: Cryogenic treatment, steel, martensitic transformation
Dieser Beitrag befasst sich mit der Auswirkung von Behandlungen unter null Grad Celsius bei kryogenen Temperaturen auf die Stahlmikrostruktur. Es wird gezeigt, dass die Bildung von Martensit, einschließlich des sogenannten isothermen, d. h. zeitabhängigen oder thermisch aktivierten, martensitischen Produkts, eine Erklärung für die Beobachtungen in der Literatur liefern kann, dass sowohl die Temperatur der Tieftemperaturbehandlung als auch die Haltezeit bei Tieftemperatur einen Einfluss auf die Leistung von Stahlprodukten im Betrieb haben kann. Dieser Überblick zeichnet die wichtigsten Etappen in der Entwicklung der Tieftemperaturbehandlungen in den letzten 95 Jahren nach und beschreibt sie parallel zur Beschreibung des aktuellen Standes des Verständnisses der Kinetik der martensitischen Umwandlung in Stahl. Im letzten Teil des Beitrags werden die neuen Erkenntnisse mit einem praktischen Beispiel in Zusammenhang gebracht, bei dem verschiedene Arten von Behandlungen unter null Grad Celsius angewendet werden.

Schlüsselwörter: Tieftemperaturbehandlung, Stahl, martensitische Umwandlung

Authors/Autoren: Dr. Matteo Villa, Prof. Dr. Ir. Marcel A. J. Somers, Technical University of Denmark, Produktionstorvet b. 425, DK 2800 Kongens Lyngby, Denmark, matv@mek.dtu.dk (corresponding author/Kontakt)

HOW TO CITE THIS ARTICLE: M. Villa et al.: On the Role of Isothermal Martensite Formation during Cryogenic Treatment of Steels. HTM J. Heat Treatm. Mat. 75 (2020) 5, pp. 263-286, DOI:10.3139/105.110420

\section{Treatment of materials with cold: a twentieth century change of perspective}

The properties of (solid) materials are determined by their chemical composition as well as by the manufacturing and processing parameters, among which the application of thermal treatments. For centuries, engineers have applied heat to thermally-treat materials at such a large scale that thermal treatments are commonly referred to as heat treatments. At the beginning of the 20th century, the availability of cryogenic liquids introduced an alternative

\section{Die Behandlung von Materialien mit Kälte: ein Perspektivwechsel im zwanzigsten Jahrhundert}

Die Eigenschaften von (festen) Materialien werden durch ihre chemische Zusammensetzung sowie durch die Herstellungs- und Verarbeitungsparameter bestimmt, darunter die Anwendung von Wärmebehandlungen. Seit Jahrhunderten wenden Ingenieure Wärme auf Materialien in so großem Umfang an, dass solche Behandlungen allgemein als Wärmebehandlungen bezeichnet werden. Zu Beginn des 20. Jahrhunderts wurde mit der Verfügbarkeit

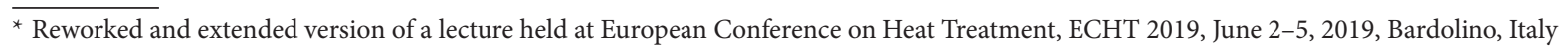


way to perform thermal treatments: using cold environments, rather than heat. Along the years it has been reported that treatments at temperatures below zero degrees Celsius can positively affect the properties of, among others, metals, polymers (see recent reviews in [1,2]) and metallic glasses [3]. There are essentially two ways in which a sub-zero Celsius treatment can contribute to a permanent (and potentially beneficial) change in material properties: by introducing localized plastic phenomena or by promoting a solid-state phase transition.

The origin for plastic phenomena is the presence of internal stresses that exceeds the elastic limit of the material. Stresses can exist on various scales. On a macroscopic scale, stresses can arise from a temperature gradient along the treated part. On a microscopic scale, in single-phase polycrystalline materials, stresses can originate from the anisotropic response of the crystal structure to temperature changes, while in multi-phase materials stresses can be the consequence of a different thermal response of the various phases. On the atomic scale, stresses, or rather strains, can buildup when local chemical inhomogeneities determine a spectrum of local responses of the material to temperature changes. Crack hazard suggests minimization of internal stresses during sub-zero Celsius treatments: The large majority of materials is brittle at sub-zero Celsius temperatures, so in the presence of stresses exceeding the elastic limit, cracks are more likely to form, than (potentially beneficial) plastic phenomena.

The progress of phase transitions requires the presence of a chemical driving force for the transition and sufficient thermal energy to effectively overcome the involved energy barriers. Treatment of materials at sub-zero Celsius temperatures can promote solid-state phase transformations by increasing the chemical driving force. Conversely, at these temperatures thermal energy is limited, thereby retarding or even preventing transformations to proceed. Longrange diffusion phenomena are essentially prevented, so the only possible transformations are diffusionless, i.e. martensitic and twinning. The conceptualization of sub-zero Celsius treatments can be ascribed to the most famous martensitic transformation in metallurgy, that enables the hardening of steel.

\section{The concept of cryogenic treatment and the initial refusal}

Conventional hardening of steel consists of promoting the diffusionless transformation of (soft) austenite into (hard) martensite by cooling the material from a temperature where austenite is stable, $\mathrm{T}>\mathrm{A} 3$, to room temperature at a sufficiently high rate to suppress the (time-dependent) formation of other transformation products such as bainite, pearlite, massive alpha, .... According to common experience, and as conveyed in standard materials science and engineering text books, during quenching, martensite kryogener Flüssigkeiten eine alternative Methode zur Durchführung von thermischen Behandlungen eingeführt: die Verwendung kalter Umgebungen anstelle von warmen. Im Laufe der Jahre wurde berichtet, dass Behandlungen bei Temperaturen unter null Grad Celsius die Eigenschaften von u. a. Metallen, Polymeren (siehe neuere Übersichtsartikel in $[1,2]$ ) und metallischen Gläsern positiv beeinflussen können [3]. Es gibt im Wesentlichen zwei Möglichkeiten, wie eine Behandlung bei Temperaturen unter null Grad Celsius zu einer dauerhaften (und potenziell vorteilhaften) Veränderung der Materialeigenschaften beitragen kann: durch die Einführung lokalisierter plastischer Phänomene oder durch die Fortsetzung einer Phasenumwandlung.

Der Ursprung für plastische Phänomene ist das Vorhandensein von inneren Spannungen, die die Elastizitätsgrenze des Materials überschreiten. Spannungen können auf verschiedenen Skalen existieren. Makroskopisch können Spannungen durch einen Temperaturgradienten entlang des behandelten Teils entstehen. Mikroskopisch können Spannungen in einphasigen polykristallinen Materialien von der anisotropen Reaktion der Kristallstruktur auf Temperaturänderungen herrühren, während in mehrphasigen Materialien Spannungen die Folge einer unterschiedlichen thermischen Reaktion der verschiedenen Phasen sein können. Auf atomarer Ebene können sich Spannungen bzw. Dehnungen aufbauen, wenn lokale chemische Inhomogenitäten ein Spektrum von lokalen Reaktionen des Materials auf Temperaturänderungen bestimmen. Die Rissgefahr deutet auf eine Minimierung der inneren Spannungen bei Behandlungen unter null Grad Celsius hin. Die große Mehrheit der Materialien ist bei Temperaturen unter null Grad Celsius spröde. Bei Vorhandensein von Spannungen, die die Elastizitätsgrenze überschreiten, bilden sich eher Risse als (vorteilhafte) plastische Dehnungen.

Das Fortschreiten von Phasenumwandlungen erfordert das Vorhandensein einer chemischen Triebkraft für die Umwandlung und eine ausreichende thermische Energie, um die beteiligten Energiebarrieren wirksam zu überwinden. Die Behandlung von Materialien bei Temperaturen unter null Grad Celsius kann Festkörper-Phasenumwandlungen fördern, indem die chemische Triebkraft erhöht wird. Umgekehrt ist bei diesen Temperaturen die thermische Energie begrenzt, wodurch der Ablauf der Umwandlungen verzögert oder sogar verhindert wird. Weiträumige Diffusionsphänomene werden im Wesentlichen verhindert, sodass nur diffusionslose, d. h. martensitische und zwillingsbildende Umwandlungen möglich sind. Die Konzeptualisierung von Behandlungen unter null Grad Celsius kann auf die berühmteste, nämlich die martensitische Umwandlung in der Metallurgie zurückgeführt werden, die das Härten von Stahl ermöglicht.

\section{Das Konzept der Tieftemperaturbehand- lung und die anfängliche Ablehnung}

Konventionelles Härten von Stahl besteht darin, die diffusionslose Umwandlung von (weichem) Austenit in (harten) Martensit zu fördern, indem das Material von einer Temperatur, bei der Austenit stabil ist, $\mathrm{T}>\mathrm{A}_{3}$, auf Raumtemperatur mit einer ausreichend hohen Geschwindigkeit abgekühlt wird, um die zeitabhängige, (nämlich diffusionsgesteuerte) Bildung anderer Umwandlungsprodukte wie Bainit, Perlit, massives Alpha, .... zu unterdrücken. Nach allgemeiner Erfahrung und wie in den Lehrbüchern der Standardwerkstoff- 
starts to form below a characteristic temperature, the martensite start temperature, $\mathrm{M}_{\mathrm{s}}$, and the transformation proceeds with decreasing temperature until a second characteristic temperature, the martensite finish temperature, $\mathrm{M}_{\mathrm{f}}$, is reached. The transformation would not be suppressible by (infinitely) fast cooling and does not progress if cooling is interrupted. Furthermore, the amount of martensite formed would be given by the lowest temperature reached. This means that the transformation is athermal, or independent of time. Time-Temperature-Transformation-(TTT-)diagrams, in use since the 1940ies, illustrate the difference between athermal and time-dependent transformations [4]. In Figure 1 a schematic TTT diagram is given. Time-dependent transformations are represented by $\mathrm{C}$-curves to indicate that the fraction transformed depends on both time and temperature. Time-dependent transformations occur at high temperatures and are thermally-activated. Martensitic transformations occur at low temperatures and are represented by horizontal lines to indicate that the transformed fraction depends only on the lowest reached temperature, not on time, and thus form instantaneously on reaching that temperature. The Koistinen-Marburger (K-M) equation, introduced in 1959 [5], expresses athermal behavior mathematically:

$f=1-\exp \left[-\alpha \times\left(\mathrm{M}_{\mathrm{s}}-\mathrm{T}_{\mathrm{q}}\right)\right]$

where $f$ is the fraction of martensite, $\alpha$ is a parameter that depends on the chemical composition of the steel [6], $\mathrm{T}_{\mathrm{q}}$ is the lowest reached temperature during quenching and the equation is valid for $\mathrm{M}_{\mathrm{s}}>\mathrm{T}_{\mathrm{q}}>-80^{\circ}$.

Depending on the values for $M_{s}$ and $\alpha$ in the K-M equation, the austenite-to-martensite transformation can be largely incomplete after conventional quenching to room temperature. Moreover, the transformation never reaches completion. In 1925, about three decades before the K-M equation was conceived, Mathews was the first to show that a significant fraction of austenite may remain untransformed in hardened martensitic steels upon reach- wissenschaft und -technik vermittelt wird, beginnt sich während des Abschreckens Martensit unterhalb einer charakteristischen Temperatur, der Martensit-Starttemperatur, $\mathrm{M}_{\mathrm{s}}$, zu bilden, und die Umwandlung verläuft mit abnehmender Temperatur, bis eine zweite charakteristische Temperatur, die Martensit-Finishtemperatur, $\mathrm{M}_{\mathrm{f}}$, erreicht ist. Die Umwandlung wäre durch (unendlich) schnelles Abkühlen nicht unterdrückbar und schreitet bei Unterbrechung der Abkühlung nicht fort. Außerdem wäre die Menge des gebildeten Martensits durch die niedrigste erreichte Temperatur gegeben. Dies bedeutet, dass die Umwandlung athermisch oder zeitunabhängig ist. Zeit-Temperatur-Umwandlungs-(ZTU-)Diagramme, die seit den 1940er Jahren verwendet werden, veranschaulichen den Unterschied zwischen athermischen und zeitabhängigen Transformationen [4]. In Bild 1 ist ein schematisches ZTU-Schaubild dargestellt. Zeitabhängige Transformationen werden durch C-Kurven dargestellt, um anzuzeigen, dass der transformierte Anteil sowohl von der Zeit als auch von der Temperatur abhängt. Zeitabhängige Transformationen treten bei hohen Temperaturen auf und werden thermisch aktiviert. Martensitische Umwandlungen treten bei niedrigen Temperaturen auf und werden durch horizontale Linien dargestellt, um anzuzeigen, dass der umgewandelte Anteil nur von der niedrigsten erreichten Temperatur und nicht von der Zeit abhängt und sich daher sofort bei Erreichen dieser Temperatur bildet. Die Koistinen-Marburger (K-M)-Gleichung, die 1959 [5] eingeführt wurde, drückt das athermische Verhalten mathematisch aus:

$f=1-\exp \left[-\alpha \times\left(\mathrm{M}_{\mathrm{s}}-\mathrm{T}_{\mathrm{q}}\right)\right]$

wobei $f$ der Martensitanteil ist, $\alpha$ ist ein Parameter, der von der chemischen Zusammensetzung des Stahls abhängt [6], $\mathrm{T}_{\mathrm{q}}$ ist die niedrigste erreichte Temperatur während des Abschreckens. Die Gleichung gilt für $\mathrm{M}_{\mathrm{s}}>\mathrm{T}_{\mathrm{q}}>-80^{\circ}$.

In Abhängigkeit von den Werten für $\mathrm{M}_{\mathrm{s}}$ und $\alpha$ in der K-MGleichung kann die Austenit-Martensit-Umwandlung nach konventionellem Abschrecken auf Raumtemperatur weitgehend unvollständig sein. Diese Umwandlung ist nie vollständig. Im Jahre 1925, etwa drei Jahrzehnte vor der Aufstellung der K-M-Gleichung, zeigte Mathews als erster, dass ein bedeutender Anteil des Austenits in gehärteten martensitischen Stählen bei Erreichen der

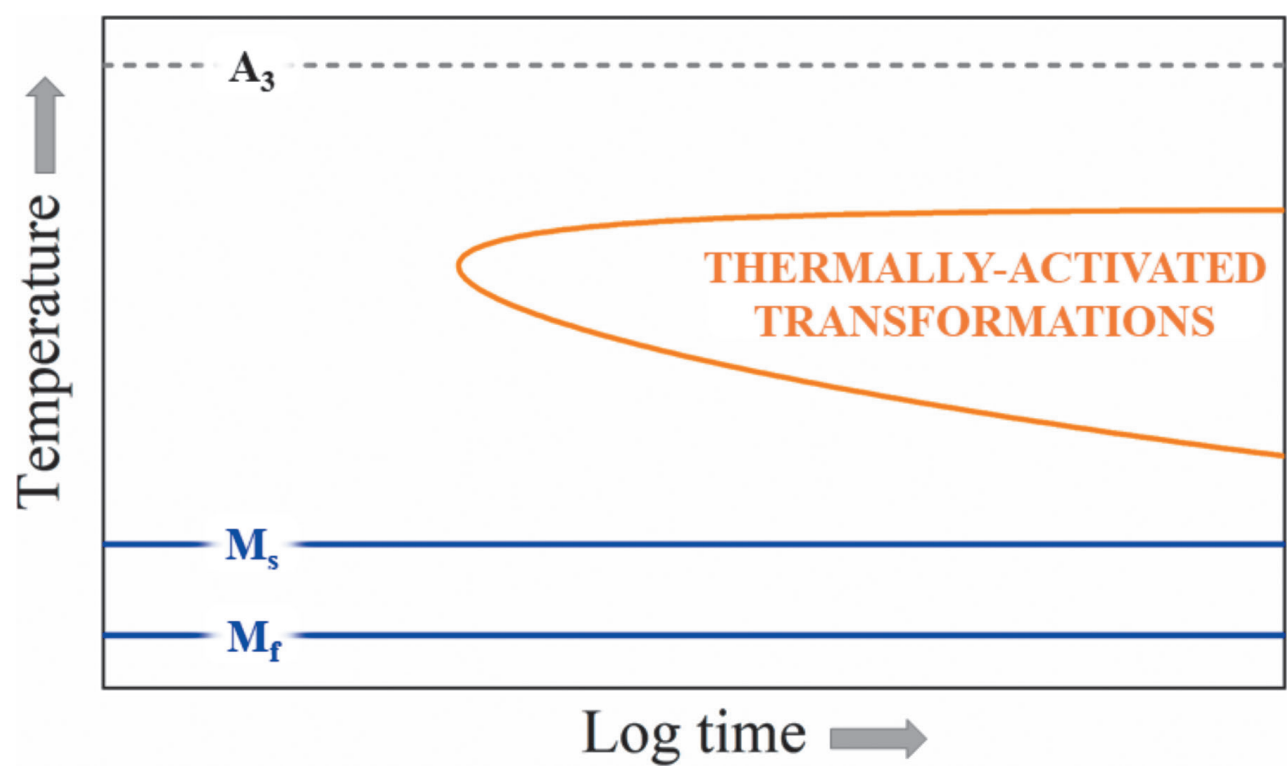

Fig. 1. Schematic TTT diagram illustrating the difference between athermal and thermally activated transformations

Bild 1. Schematisches ZTU-Schaubild zur Veranschaulichung des Unterschieds zwischen athermischen und thermisch aktivierten Transformationen 
ing room temperature [7]. Mathews labeled this austenite retained austenite (RA) and claimed that it is present in all medium and high carbon steels after conventional hardening. Mathews also suggested that RA limits the achievable hardness in steel, as austenite is much softer than martensite. To reduce the fraction of RA, Mathews proposed to further reduce the temperature after conventional hardening by cooling below zero Celsius, for example by immersion of the parts in liquid air, i. e. to $-183^{\circ} \mathrm{C}$. In the two following decades, Mathews' hypothesis was confirmed by various authors, of which Gulyaev [8] and Cohen and his co-workers $[9,10]$ are probably best known. In particular, Cohen et al. showed that the austenite-to-martensite transformation continues in steel on cooling to $-150^{\circ} \mathrm{C}$; further cooling would be ineffective. Moreover, they suggested that the transformation does not progress isothermally if the cooling process is interrupted and does not take place during re-heating of the material to room temperature. Thus, they established the idea that martensite formation is athermal. Consequently, the austenite that has not transformed at $-150{ }^{\circ} \mathrm{C}$ is retained.

Nowadays, it is well established that RA is present in conventionally hardened steel parts when the carbon content dissolved in austenite prior to quenching exceeds $0.2 \mathrm{wt} .-\%$ [11] and the fraction of RA can be reduced, but not eliminated, by sub-zero Celsius treatments. Moreover, it is known that sub-zero Celsius treatments can lead to hardness values otherwise impossible to obtain for steel parts. In Figure 2, plain C steel is taken as an example to illustrate these concepts. The data shows that adding $\mathrm{C}$ increases the fraction of RA at room temperature, which reflects that $\mathrm{C}$ strongly reduces $M_{s}[12]$. Nevertheless, $C$ is added to Fe to confer addition-

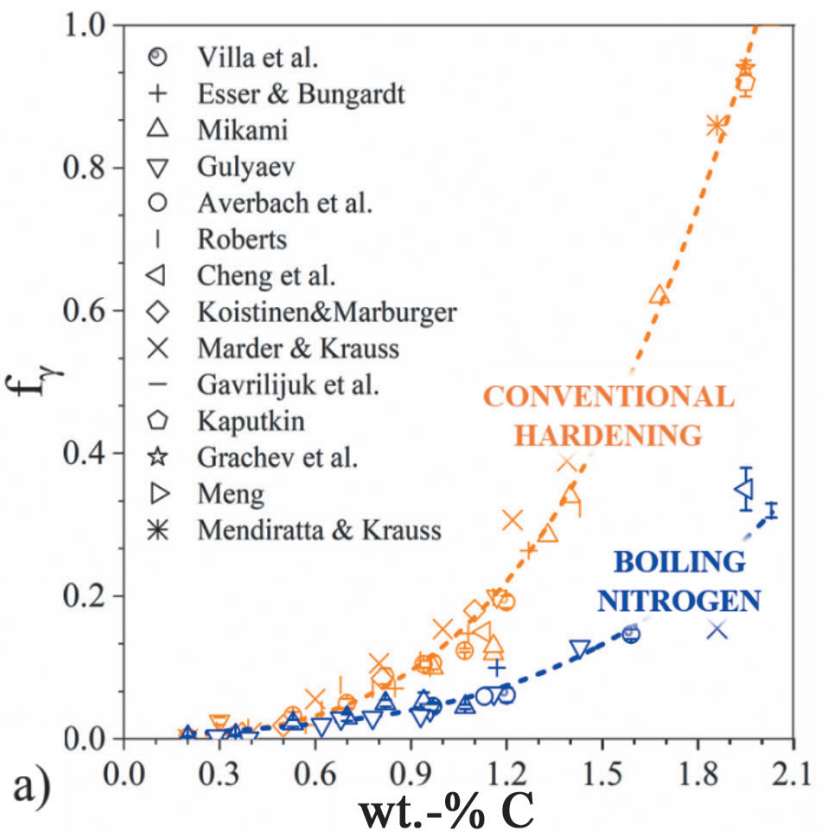

Raumtemperatur erhalten bleiben kann [7]. Mathews bezeichnete diesen Austenit als Restaustenit (RA) und behauptete, dass er in allen Stählen mit mittlerem und hohem Kohlenstoffgehalt nach konventioneller Härtung vorhanden ist. Mathews schlug auch vor, dass RA die erreichbare Härte in Stahl begrenzt, da Austenit viel weicher als Martensit ist. Um den Anteil von RA zu reduzieren, schlug Mathews vor, die Temperatur nach dem konventionellen Härten durch Abkühlen unter null Grad Celsius weiter zu senken, z. B. durch Eintauchen der Teile in flüssige Luft, d. h. auf $-183^{\circ} \mathrm{C}$. In den beiden folgenden Jahrzehnten wurde Mathews Hypothese von verschiedenen Autoren bestätigt, von denen Gulyaev [8] und Cohen und seine Mitarbeitenden [9, 10] wohl am bekanntesten sind. Cohen et al. zeigten insbesondere, dass sich die AustenitMartensit-Umwandlung im Stahl bei einer Abkühlung auf $-150{ }^{\circ} \mathrm{C}$ fortsetzt; eine weitere Abkühlung wäre wirkungslos. Darüber hinaus schlugen sie vor, dass die Umwandlung nicht isotherm fortschreitet, wenn der Abkühlungsprozess unterbrochen wird und nicht während der Wiedererwärmung des Materials auf Raumtemperatur stattfindet. Sie begründeten damit die Idee, dass die Martensitbildung athermisch ist. Folglich bleibt der Austenit, der sich bei $-150{ }^{\circ} \mathrm{C}$ nicht umgewandelt hat, erhalten.

Heutzutage ist es allgemein bekannt, dass RA in konventionell gehärteten Stahlteilen vorhanden ist, wenn der vor dem Abschrecken im Austenit gelöste Kohlenstoffgehalt 0,2 Gew.-\% überschreitet [11] und der Anteil von RA durch Behandlungen unter null Grad Celsius reduziert, aber nicht eliminiert werden kann. Darüber hinaus ist bekannt, dass Behandlungen unter null Grad Celsius zu Härtewerten führen können, die sonst für Stahlteile unmöglich zu erreichen sind. In Bild 2 wird einfacher C-Stahl als Beispiel genommen, um diese Konzepte zu veranschaulichen. Die Daten zeigen, dass die Zugabe von Kohlenstoff den Anteil von RA bei

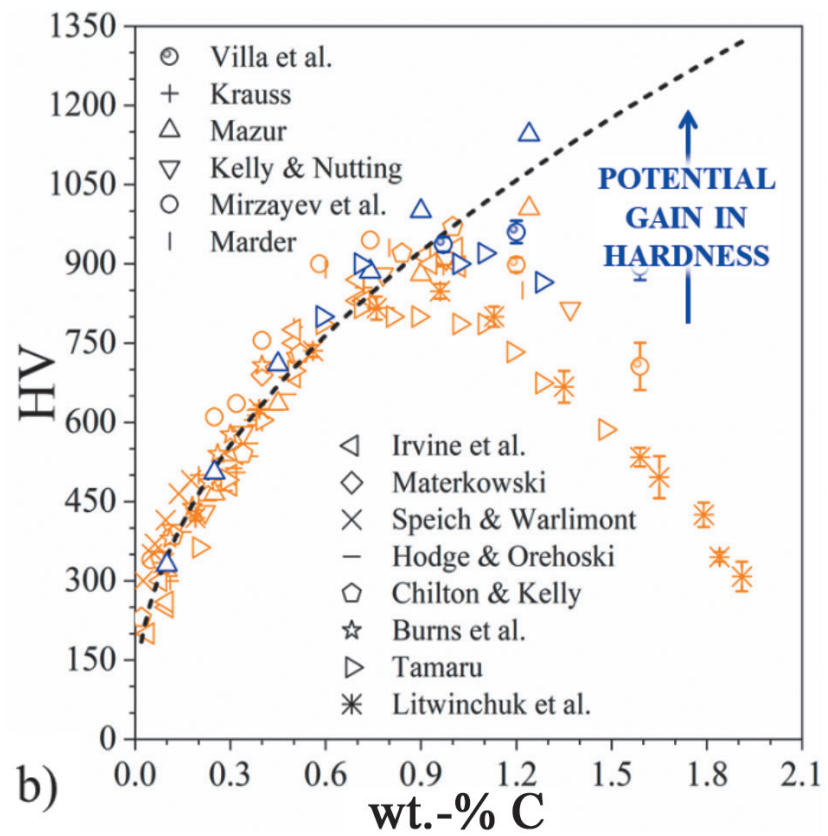

Fig. 2. a) Fraction of retained austenite and b) Vickers Hardness of plain Carbon steels measured after conventional quenching - orange symbols - and after additional cryogenic treatment - blue symbol -. References can be found in [11].The black line in b) illustrates the potential hardness of a fully martensitic sample

Bild 2. a) Anteil des Restaustenits und b) Vickershärte von unlegierten Kohlenstoffstählen, gemessen nach konventionellem Abschrecken - orangefarbene Symbole - und nach zusätzlicher Tieftemperaturbehandlung - blaue Symbole. Die Referenzen sind in [11] zu finden. Die schwarze Linie in b) veranschaulicht die potenzielle Härte einer vollmartensitischen Probe 
al strength, as manifested by the hardness. The hardness of $\mathrm{C}$ steel at room temperature increases with $\mathrm{C}$ content up to approximately $1 \mathrm{wt} .-\%$ for which a maximum hardness of approximately $900 \mathrm{HV}$ is reached. Upon further increase of the $\mathrm{C}$ content, the hardness decreases. This implies that the increase in the fraction of soft RA is no longer compensated by the hardness increase achieved by dissolving more $\mathrm{C}$ in martensite. Reducing the fraction of RA by treatment in the sub-zero Celsius temperature regime shifts the point of maximum hardness to approximately $1.2 \mathrm{wt} .-\% \mathrm{C}$ and the corresponding hardness values exceed $1000 \mathrm{HV}$.

In the early years of applying sub-zero Celsius treatment, focus was on medium and high $\mathrm{C}$ steels for tooling, where hardness is paramount. Moreover, applications for these steel grades require high dimensional stability. In tool steels, the fraction of RA after conventional hardening can be significant. The reduction of the fraction of RA by a sub-zero Celsius treatment can increase hardness and simultaneously provides improved dimensional stability: RA can transform into martensite in service, causing a shape change and, eventually, failure. In spite of the work by Cohen and Gulyaev showing the positive effect of sub-zero Celsius treatment on both mechanical properties and dimensional stability, industrial application of such treatments was initially fierily criticized because of crack hazard: medium and high $\mathrm{C}$ steels are generally brittle; exposing brittle materials to very low temperature did not appear to be a clever idea. Sub-zero Celsius treatments of steels containing a significant fraction of $\mathrm{C}$ had to wait until the mid1970 ies to be accepted in industry. The key factor for acceptance was the introduction of programmable cryogenic refrigerators, where the (slow) cooling rate of steel parts could be controlled. This technology reduced crack hazard when compared to immersion of the parts in cryogenic liquids. Meanwhile, subzero Celsius treatments found application as a method to form martensite in a special class of low $\mathrm{C}$, highly alloyed semi-austenitic precipitation hardenable, $\mathrm{PH}$, stainless steels, which were firstly introduced in the late 1940ies [13].

\section{The first application and the break of the athermal paradigm for martensite formation}

PH stainless steels are very high strength steels, where the high strength is obtained by conversion of austenite into martensite followed by the precipitation of nano-crystalline intermetallic particles within the martensite during tempering. As such, the $\mathrm{C}$ content can be kept at a low level. In semi-austenitic $\mathrm{PH}$ grades, $\mathrm{M}_{\mathrm{s}}$ lies at about room temperature and the conversion of austenite into martensite can be obtained by sub-zero Celsius treatment. According to the specifications [13], these steels should be sub-zero Celsius treated at approximately $-70^{\circ} \mathrm{C}$ for eight hours, a treatment that is conveniently performed in ethanol with excess of dry ice
Raumtemperatur erhöht, was zeigt, dass Kohlenstoff die $\mathrm{M}_{\mathrm{s}}$-Temperatur stark senkt [12]. Nichtsdestotrotz wird C zu Fe hinzugefügt, um zusätzliche Festigkeit zu verleihen, was sich in der Härte manifestiert. Die Härte von C-Stahl bei Raumtemperatur nimmt mit dem C-Gehalt bis zu etwa 1 Gew.- $\%$ zu, wobei eine maximale Härte von etwa 900 HV erreicht wird. Bei weiterer Erhöhung des C-Gehaltes nimmt die Härte ab. Dies bedeutet, dass die Zunahme des Anteils an weichem RA nicht mehr durch die Härtezunahme, die durch das Auflösen von mehr C in Martensit erreicht wird, kompensiert wird. Die Verringerung des Anteils an RA durch Behandlung im Temperaturbereich unter null Grad Celsius verschiebt den Punkt der maximalen Härte auf etwa 1,2 Gew.-\% C und die entsprechenden Härtewerte übersteigen $1000 \mathrm{HV}$.

In den ersten Jahren der Anwendung der Unter-Null-Grad-CelsiusBehandlung lag der Schwerpunkt auf Stählen mit mittlerem und hohem C-Gehalt für den Werkzeugbau, wo die Härte von größter Bedeutung ist. Darüber hinaus erfordern Anwendungen für diese Stahlsorten eine hohe Maßbeständigkeit. Bei Werkzeugstählen kann der Anteil an RA nach konventioneller Härtung erheblich sein. Die Reduzierung des Anteils an RA durch eine Behandlung unter null Grad Celsius kann die Härte erhöhen und gleichzeitig eine verbesserte Dimensionsstabilität bewirken: RA kann sich im Betrieb in Martensit umwandeln, was zu einer Formänderung und schließlich zum Versagen führen kann. Trotz der Arbeiten von Cohen und Gulyaev, die die positive Wirkung einer Behandlung unter null Grad Celsius sowohl auf die mechanischen Eigenschaften als auch auf die Dimensionsstabilität zeigten, wurde die industrielle Anwendung solcher Behandlungen zunächst wegen der Rissgefahr heftig kritisiert. Stähle mit mittlerem und hohem C-Gehalt sind im Allgemeinen spröde. Spröde Materialien sehr niedrigen Temperaturen auszusetzen, schien keine kluge Idee zu sein. Behandlungen bei Temperaturen unter null Grad Celsius von Stählen, die einen signifikanten Anteil an C enthalten, mussten bis Mitte der 1970er Jahre warten, um in der Industrie akzeptiert zu werden. Der Schlüsselfaktor für die Akzeptanz war die Einführung programmierbarer Tieftemperaturkühlschränke, in denen die (langsame) Abkühlgeschwindigkeit von Stahlteilen kontrolliert werden konnte. Diese Technologie verringerte die Rissgefahr im Vergleich zum Eintauchen der Teile in kryogene Flüssigkeiten. In der Zwischenzeit fanden Behandlungen unter null Grad Celsius Anwendung als Methode zur Bildung von Martensit in einer speziellen Klasse von hochlegierten halbaustenitischen ausscheidungshärtbaren PH-Edelstählen mit niedrigem C-Gehalt, die erstmals in den späten 1940er Jahren eingeführt wurden [13].

\section{Die erste Anwendung und der Bruch des athermischen Paradigmas zur Martensitbildung}

PH-Edelstähle sind sehr hochfeste Stähle, bei denen die hohe Festigkeit durch die Umwandlung von Austenit in Martensit erreicht wird, gefolgt von der Ausscheidung von nanokristallinen intermetallischen Teilchen innerhalb des Martensits beim nachfolgenden Anlassen. Als solches kann der C-Gehalt auf einem niedrigen Niveau gehalten werden. Bei semi-austenitischen PH-Güten liegt $\mathrm{M}_{\mathrm{s}}$ etwa bei Raumtemperatur, und die Umwandlung von Austenit in Martensit kann durch eine Behandlung bei Temperaturen unter null Grad Celsius erreicht werden. Gemäß den Spezifikationen [13] sollten diese Stähle acht Stunden lang bei etwa $-70^{\circ} \mathrm{C}$ unter 
$\left(-78^{\circ} \mathrm{C}\right)$. In the light of the athermal paradigm for the austenite-to-martensite transformation (see Fig. 1) the long holding step at $-78^{\circ} \mathrm{C}$ finds no reasonable explanation. A hypothesis is that martensite formation in these steels proceeds isothermally, implying that the transformation is time-dependent.

Time-dependent martensite formation in steel was firstly reported by Kurdjumov and Maksimova in the late 1940ies [14] and was, at least until the mid-1990ies, considered an anomaly and limited to a few exotic systems with no practical implications. On the other hand, already in 1960, Gulyaev and Makarov [15] showed that in 15-7 PH stainless steels (AISI 632 grade: $15 \mathrm{Cr}-7 \mathrm{Ni}-2 \mathrm{Mo}-1 \mathrm{Al}-0.1 \mathrm{C}$, in wt.-\%) austenite can transform into martensite during cooling from room temperature to $-196^{\circ} \mathrm{C}$ and, likewise, during re-heating within the same temperature interval. Moreover, it was shown that fast cooling to $-196^{\circ} \mathrm{C}$, as obtained by immersion in boiling nitrogen, fully suppresses the transformation. These observations point towards a thermally activated, i. e. time-dependent, process.

The thermally activated character of the transformation in 15-7 $\mathrm{PH}$ stainless steel was confirmed in recent studies in our laboratories [16]. In the initial conditions, the material under investigation contained approximately $82 \%$ austenite, the rest consisted of delta ferrite and (possibly a minor fraction) martensite. This material was subjected to sub-zero Celsius treatment and the evolution of martensite formation was monitored with magnetometry. Magnetometry measures the changes in saturation magnetization and, hence, allows following the austenite-to-martensite transformation while it is happening, at a precision better than $0.1 \%$. Its major limits are that it cannot distinguish between ferrite and martensite and it cannot reveal the formation of $\varepsilon$ martensite (i. e. martensite with hexagonal crystal structure that forms in steels with low stacking fault energy). Figure 3 shows two TTT diagrams for the conversion of austenite into martensite at sub-zero Celsius temperatures as constructed with the acquired data. In one case the material was cooled from room temperature to the temperatures of isothermal investigation; in the second case, the material was first immersed in boiling nitrogen, during which virtually no $(<1 \%)$, transformation took place, and thereafter heated to the isothermal transformation temperature. Data shows that the null Grad Celsius behandelt werden, eine Behandlung, die bequem in Ethanol mit Trockeneisüberschuss $\left(-78^{\circ} \mathrm{C}\right)$ durchgeführt wird. Im Licht des athermischen Paradigmas für die Austenit-Martensit-Umwandlung (siehe Bild 1) findet der lange Halteschritt bei $-78^{\circ} \mathrm{C}$ keine vernünftige Erklärung. Eine Hypothese ist, dass die Martensitbildung in diesen Stählen isotherm verläuft, was impliziert, dass die Umwandlung zeitabhängig ist.

Die zeitabhängige Martensitbildung in Stahl wurde erstmals Ende der 1940er Jahre [14] von Kurdjumov und Maksimova berichtet und wurde, zumindest bis Mitte der 1990er Jahre, als Anomalie betrachtet und auf einige wenige exotische Systeme ohne praktische Auswirkungen beschränkt. Andererseits zeigten Gulyaev und Makarov [15] bereits 1960, dass sich Austenit in rostfreien Stählen mit 15-7 PH (AISI 632 : 15Cr-7Ni-2Mo-1Al-0,1C, in Gew.-\%) beim Abkühlen von Raumtemperatur auf $-196^{\circ} \mathrm{C}$ und ebenso beim Wiedererwärmen innerhalb desselben Temperaturintervalls in Martensit umwandeln kann. Außerdem wurde gezeigt, dass eine schnelle Abkühlung auf $-196^{\circ} \mathrm{C}$, wie sie durch Eintauchen in siedenden Stickstoff erreicht wird, die Umwandlung vollständig unterdrückt. Diese Beobachtungen deuten auf einen thermisch aktivierten, d. h. zeitabhängigen Prozess hin.

Der thermisch aktivierte Charakter der Umwandlung in rostfreiem Stahl 15-7 PH wurde in neueren Studien in unseren Labors bestätigt [16]. Unter den Ausgangsbedingungen enthielt das untersuchte Material ca. 82 \% Austenit, der Rest bestand aus Deltaferrit und (möglicherweise einem geringen Anteil) Martensit. Dieses Material wurde einer Behandlung unter null Grad Celsius unterzogen, und die Entwicklung der Martensitbildung wurde magnetometrisch überwacht. Die Magnetometrie misst die Änderungen der Sättigungsmagnetisierung und ermöglicht es daher, die Austenit-Martensit-Umwandlung mit einer Genauigkeit von mehr als $0,1 \% \mathrm{zu}$ verfolgen, während sie stattfindet. Ihre Hauptgrenzen liegen darin, dass sie nicht Ferrit von Martensit unterscheiden kann und dass die Bildung von $\varepsilon$-Martensit (d. h. Martensit mit hexagonaler Kristallstruktur, das sich in Stählen mit niedriger Stapelfehlerenergie bildet) nicht aufgedeckt werden kann. Bild 3 zeigt zwei ZTU-Schaubilder für die Umwandlung von Austenit in Martensit bei Temperaturen unter null Grad Celsius, wie sie mit den erfassten Daten konstruiert wurden. In einem Fall wurde das Material von Raumtemperatur auf die Temperaturen der isothermen Untersuchung abgekühlt; im zweiten Fall wurde das Material zunächst in siedenden Stickstoff getaucht, währenddessen praktisch keine
Fig. 3. TTT diagrams for the conversion of austenite into martensite in 15-7 PH stainless steel obtained for two different initial treatment conditions: conventional cooling from room temperature to the isothermal transformation temperature; immersion in boiling nitrogen and re-heating to isothermal transformation temperature. Details of the investigation can be found in $[16]$

Bild 3. ZTU-Schaubilder für die Umwandlung von Austenit in Martensit in rostfreiem Stahl mit 15-7 PH erhalten für zwei verschiedene Anfangsbehandlungsbedingungen: konventionelle Abkühlung von Raumtemperatur auf die isotherme Umwandlungstemperatur; Eintauchen in siedenden Stickstoff und Wiedererwärmen auf die isotherme Umwandlungstemperatur Einzelheiten der Untersuchung sind in [16] zu finden

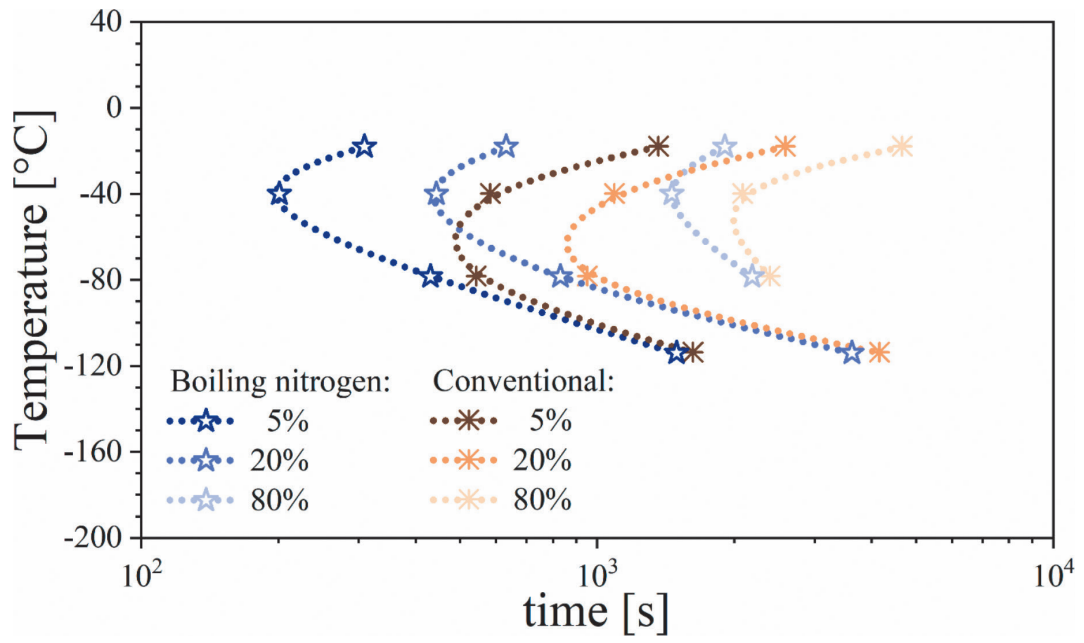


transformation of the austenite into martensite at sub-zero Celsius temperatures can be expressed by $\mathrm{C}$-curves, typical for thermally activated processes. The TTT curves for the material directly cooled from room temperature show that the transformation rate is fastest at temperatures in the range $-80^{\circ}$ to $-40^{\circ} \mathrm{C}$ and an effective conversion of austenite into martensite occurs within a few hours. This is in agreement with expectations based on the specifications for this material [13]. Interestingly, pre-immersion in boiling nitrogen has a significant accelerating effect on the isothermal transformation and promotes a shift of the TTT curves towards higher temperatures and shorter times. This can be understood only in terms of an (at least partial) athermal nucleation process, that takes place during cooling of the material to boiling nitrogen temperature, followed by time dependent growth of the martensite, which occurs during the isothermal holding step.

Microscopy was applied to verify the transformation mechanism. Direct observation of the phenomenon in 15-7 PH poses experimental challenges. The attention was directed towards materials comparable to 15-7 PH. Figure 4 illustrates the isothermal formation of martensite at room temperature in $15 \mathrm{Cr}-5 \mathrm{Ni}-1 \mathrm{Mo}-\mathrm{xN}$. Here, $\mathrm{N}$ was introduced in the base material (EN 1.4418 grade) by applying an atmosphere consisting of $\mathrm{N}_{2}$ and $\mathrm{H}_{2}$ with ratio $1: 7$ during austenitization. The $\mathrm{N}_{2}$ content in the gas was tailored to optimize the stability of the austenite so that martensite formation could be followed at room temperature. Light optical images were acquired with a Olympus GX 41 reflected light microscope equipped with a Leica DFC $450 \mathrm{C}$ camera at a rate of 1 frame per minute. The first frame was acquired approximately 2 minutes af- (d. h. weniger als $1 \%$ ) Umwandlung stattfand, und danach auf die isotherme Umwandlungstemperatur erwärmt. Die Daten zeigen, dass die Umwandlung des Austenits in Martensit bei Temperaturen unter null Grad Celsius durch C-Kurven ausgedrückt werden kann, die für thermisch aktivierte Prozesse charakteristisch sind. Die ZTU-Kurven für das direkt von Raumtemperatur abgekühlte Material zeigen, dass die Umwandlungsrate bei Temperaturen im Bereich von $-80^{\circ}$ bis $-40^{\circ} \mathrm{C}$ am schnellsten ist und eine effektive Umwandlung von Austenit in Martensit innerhalb weniger Stunden stattfindet. Dies steht in Übereinstimmung mit den Erwartungen, die auf den Spezifikationen für diesen Werkstoff beruhen [13]. Interessanterweise hat die Eintauchung in siedendem Stickstoff einen signifikant beschleunigenden Effekt auf die isotherme Umwandlung und fördert eine Verschiebung der ZTU-Kurven zu höheren Temperaturen und kürzeren Zeiten. Dies kann nur im Sinne eines (zumindest teilweisen) athermischen Keimbildungsprozesses verstanden werden, der während der Abkühlung des Materials auf die Temperatur des siedenden Stickstoffs stattfindet, gefolgt von einem zeitabhängigen Wachstum des Martensits, das während des isothermen Halteschritts stattfindet.

Der Umwandlungsmechanismus wurde mikroskopisch verifiziert. Die direkte Beobachtung des Phänomens bei 15-7 PH wirft experimentelle Herausforderungen auf. Die Aufmerksamkeit wurde auf Materialien gerichtet, die mit 15-7 PH vergleichbar sind. Bild 4 zeigt die isotherme Bildung von Martensit bei Raumtemperatur in $15 \mathrm{Cr}-5 \mathrm{Ni}-1 \mathrm{Mo}-\mathrm{xN}$. Hier wurde $\mathrm{N}$ in den Grundwerkstoff (EN 1.4418) eingebracht, indem während der Austenitisierung eine Atmosphäre bestehend aus $\mathrm{N}_{2}$ und $\mathrm{H}_{2}$ im Verhältnis $1: 7$ aufgebracht wurde. Der $\mathrm{N}_{2}$-Gehalt im Gas wurde auf die Optimierung der Stabilität des Austenits abgestimmt, sodass die Martensitbildung bei Raumtemperatur verfolgt werden konnte. Lichtoptische Bilder wurden mit einem Auflichtmikroskop Olympus GX 41, ausgestattet mit einer Leica DFC 450 C-Kamera, mit einer Rate von
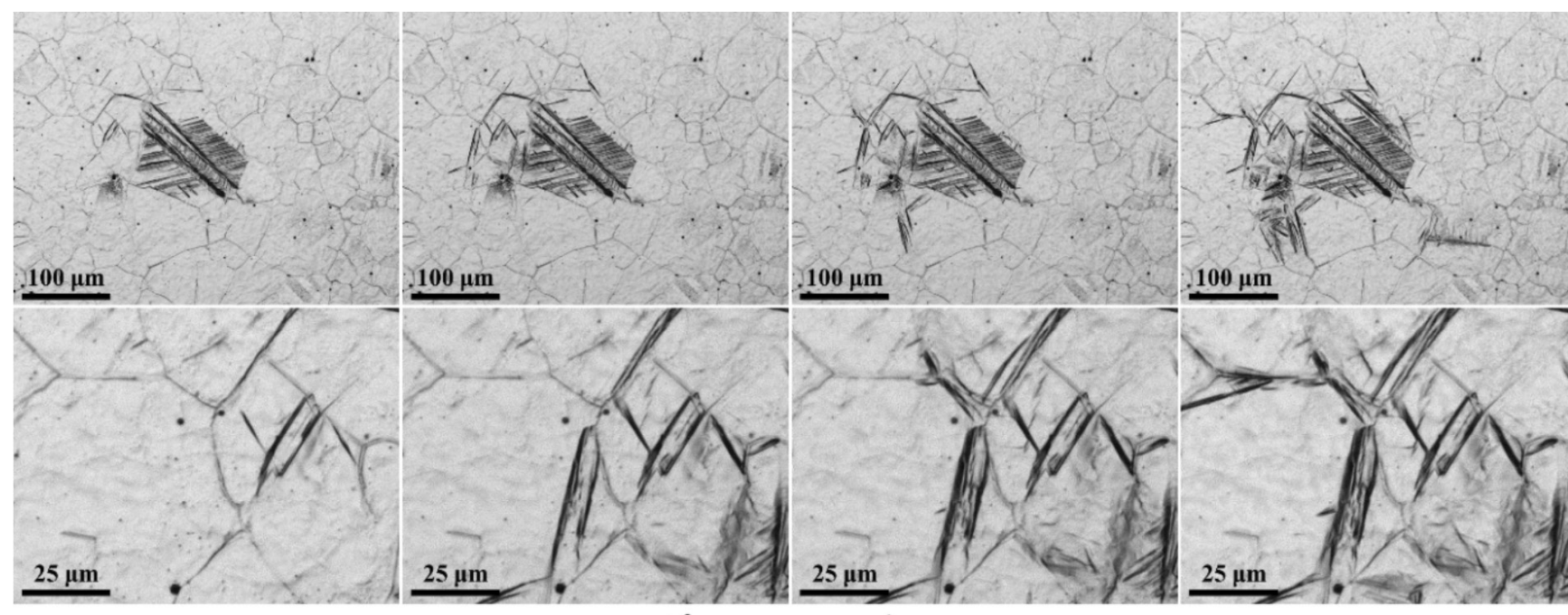

$100 \mu \mathrm{m}$

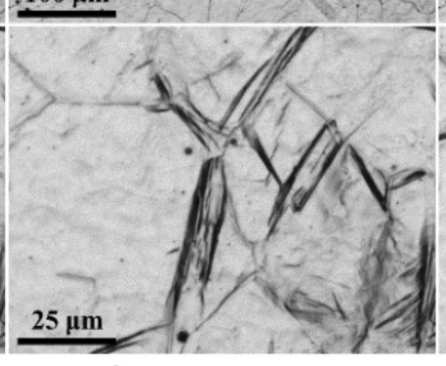

$100 \mu \mathrm{m}$
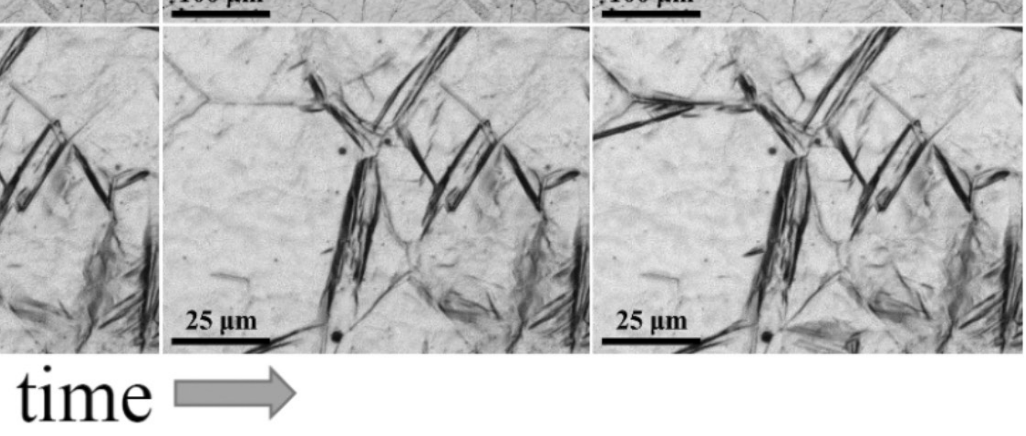

Fig. 4. Time dependent growth of martensite at room temperature in $15 \mathrm{Cr}-5 \mathrm{Ni}-1 \mathrm{Mo}-\mathrm{xN}$ steel. The low magnification micrographs in the upper row illustrate the growth of the martensite cluster.The bottom row reports $4 x$ enlargements of a location of interest where time dependent growth of the single martensite units can be observed in a few places

Bild 4. Zeitabhängiges Wachstum von Martensit bei Raumtemperatur in 15Cr-5Ni-1Mo-xN-Stahl. Die Schliffbilder mit geringer Vergrößerung in der oberen Reihe veranschaulichen das Wachstum des Martensit-Clusters. Die untere Reihe zeigt die 4x Vergrößerungen eines Ortes, an welchem zeitabhängiges Wachstum der einzelnen Martensit-Einheiten an wenigen Stellen beobachtet werden kann 
ter quenching. Figure 4 shows the first four acquired frames. Time-dependent growth of the martensite takes place at various scales of the microstructure. A nucleation event generates a unit of martensite or, eventually, a cluster of units. This cluster is initially concentrated within one prior austenite grain. Thereafter, the cluster grows over time and spreads to the neighboring grains, while the partially transformed grains are filled-out with new martensite units. Also, the growth of the single martensite units is time-dependent and thus contributes to the time-dependent increase of the martensite fraction. Evidently, martensite formation is not instantaneous and growth is not infinitely rapid, contrary to what is often presumed.

In conclusion, martensite formation in 15-7 PH steels is time-dependent and this dependence is a consequence of thermally activated growth of the martensite at various length scales of the microstructure. Time-dependent martensite formation in this system was already known in the 1960ies and exploited in the first commercial use of sub-zero Celsius treatment of steel products.

\section{Isothermal martensite at cryogenic temperatures}

The 1960ies were the years of the space race. Cryogenic engineering was a flourishing field and the related competences were spread over the USA and the USSR. This situation was clearly beneficial for the expansion of cryogenic applications in the years to come. R.F. Barron was an established researcher in the field of cryogenic engineering and from the mid-1970ies he started directing his attention to the effect of sub-zero Celsius treatments on the performance of steels containing a significant $\mathrm{C}$ content, like steels for tooling $[17,18]$. Typically, the sub-zero Celsius treatments by Barron and co-workers consisted in controlled cooling to a temperature in the interval from $-73{ }^{\circ} \mathrm{C}$ to $-196^{\circ} \mathrm{C}$ followed by an isothermal step that could be as long as $24 \mathrm{~h}$, followed by re-heating to room temperature. The research showed that the effect of sub-zero Celsius treatments was most pronounced for the lowest applied treatment temperature and the longest applied treatment time, i. e. $-196{ }^{\circ} \mathrm{C}$ for $24 \mathrm{~h}$, while long treatments at $-78^{\circ} \mathrm{C}$ were not as effective [18]. Nowadays the second (down to $-80^{\circ} \mathrm{C}$ ) are labelled cold treatments, while treatments that extend down to the temperatures typical of cryogenic liquids, say $-190^{\circ} \mathrm{C}$, are labelled cryogenic treatments [19]. The results by Barron and co-workers may suggest isothermal transformation at $-196{ }^{\circ} \mathrm{C}$ that differs from the isothermal process at temperatures typical for cold treatments. In tool steels, the microstructure is composed of martensite, RA and various types of carbides. Barron and co-workers speculated that cryogenic treatments would have promoted a modification of the carbide population and that this modification was responsible for a modified performance of tool steels in service. Nowadays, the term conditioning of martensite is used to indicate an isothermal process of undetermined nature, that takes place at cryogenic temperatures and that promotes a modification of the carbide population in the steel [20].
1 Bild pro Minute aufgenommen. Das erste Bild wurde etwa $2 \mathrm{Mi}$ nuten nach dem Abschrecken aufgenommen. Bild 4 zeigt die ersten vier aufgenommenen Bilder. Das zeitabhängige Wachstum des Martensits findet in verschiedenen Maßstäben der Mikrostruktur statt. Ein Keimbildungsereignis erzeugt eine Einheit Martensit oder schließlich ein Cluster von Einheiten. Dieses Cluster ist zunächst innerhalb eines vorhergehenden Austenitkorns konzentriert. Danach wächst der Cluster mit der Zeit und breitet sich auf die benachbarten Körner aus, während die teilweise umgewandelten Körner mit neuen Martensit-Einheiten ausgefüllt werden. Auch das Wachstum der einzelnen Martensiteinheiten ist zeitabhängig und trägt somit zur zeitabhängigen Zunahme des Martensitanteils bei. Offensichtlich ist die Martensitbildung nicht augenblicklich und das Wachstum nicht unendlich schnell, wie oft vermutet (oder angenommen) wird.

Zusammenfassend lässt sich sagen, dass die Martensitbildung in 15-7 PH-Stählen zeitabhängig ist und diese Abhängigkeit eine Folge des thermisch aktivierten Wachstums des Martensits auf verschiedenen Längenskalen der Mikrostruktur ist. Die zeitabhängige Martensitbildung in diesem System war bereits in den 1960er Jahren bekannt und wurde bei der ersten kommerziellen Nutzung der Unter-Null-Celsius-Behandlung von Stahlprodukten ausgenutzt.

\section{Isothermer Martensit bei kryogenen Temperaturen}

Die 1960er Jahre waren die Jahre des Weltraumwettlaufs. Die Tieftemperaturtechnik war ein florierendes Gebiet, und die damit verbundenen Kompetenzen waren über die USA und die UdSSR verteilt. Diese Situation war eindeutig vorteilhaft für die Ausweitung kryogener Anwendungen in den kommenden Jahren. R. F. Barron war ein etablierter Forscher auf dem Gebiet der Tieftemperaturtechnik, und ab Mitte der 1970er Jahre begann er seine Aufmerksamkeit auf die Auswirkungen von Behandlungen unter null Grad Celsius auf die Leistung von Stählen mit einem signifikanten C-Gehalt, wie Stähle für Werkzeuge [17, 18], zu lenken. Typischerweise bestanden die Unter-Null-Celsius-Behandlungen durch Barron und seinen Mitarbeitenden in einer kontrollierten Abkühlung auf eine Temperatur im Bereich von $-73^{\circ} \mathrm{C}$ bis $-196^{\circ} \mathrm{C}$, gefolgt von einem isothermen Schritt, der bis zu 24 Stunden dauern konnte, gefolgt von einer Wiedererwärmung auf Raumtemperatur. Die Forschung zeigte, dass die Wirkung von Behandlungen bei Temperaturen unter null Grad Celsius bei der niedrigsten angewandten Behandlungstemperatur und der längsten angewandten Behandlungszeit, d. h. $-196^{\circ} \mathrm{C}$ für $24 \mathrm{~h}$, am stärksten ausgeprägt war, während lange Behandlungen bei $-78^{\circ} \mathrm{C}$ nicht so wirksam waren [18]. Heutzutage werden die zweiten (bis zu $-80{ }^{\circ} \mathrm{C}$ ) als Kältebehandlungen bezeichnet, während Behandlungen, die sich bis zu den für kryogene Flüssigkeiten typischen Temperaturen, sagen wir $-190^{\circ} \mathrm{C}$, erstrecken, als Tieftemperaturbehandlungen bezeichnet werden [19]. Die Ergebnisse von Barron und seinen Mitarbeitenden deuten möglicherweise auf eine isotherme Umwandlung bei $-196{ }^{\circ} \mathrm{C}$ hin, die sich von dem isothermen Prozess bei Temperaturen unterscheidet, die für Kältebehandlungen typisch sind. Bei Werkzeugstählen setzt sich die Mikrostruktur aus Martensit, RA und verschiedenen Karbidtypen zusammen. Barron und seine Mitarbeitenden spekulierten, dass Tieftemperaturbehandlungen eine Modifikation der Karbidpopulation gefördert hätten und dass diese Modifikation für eine veränderte 
In the previous paragraph it was illustrated that prolonged cold treatments at approximately $-80{ }^{\circ} \mathrm{C}$ could find an explanation in the isothermal formation of martensite that occurs optimally at these temperatures in certain steel grades. Consistently, we tried to verify whether isothermal martensite formation could provide an explanation also for the effect of the holding time at cryogenic temperatures on the performance of numerous steels for tooling.

In 1995, Zhao and Notis [21] suggested that time-dependent martensite formation in steel is the rule, rather than an exception: as such, by applying a sufficiently high cooling rate it should always be possible to suppress the conversion of austenite into martensite. The transformation would then proceed either isothermally, when the cooling is interrupted at a sufficiently high temperature, or during re-heating. Conversely, practical experience suggests that the formation of martensite in steel is impossible to suppress, and when suppressed, it is difficult to follow under isothermal conditions. In our laboratories, various conventionally hardened steel samples were cooled as fast as possible to $-196^{\circ} \mathrm{C}$ and thereafter "isothermal" martensite formation, if any, was monitored during heating from $-196^{\circ} \mathrm{C}$ to room temperature. Isochronal (constant heating rate) conditions were applied, because such tests allow the determination of an activation energy of the thermally-activated transformation [22], giving a unique indication of the rate-determining mechanism. Monitoring of the progress of martensite formation was again accomplished with magnetometry.

The relation between isothermal and isochronal investigations is illustrated in Figure 5 that reports superimposed TTT and Continuous-Heating-Transformation, CHT, diagrams for the formation of martensite in a 17-7 PH (AISI 631 grade: $17 \mathrm{Cr}-7 \mathrm{Ni}-1 \mathrm{Al}-0.1 \mathrm{C}$, in wt.-\%) stainless steel [23]. After conventional quenching, the material was essentially austenitic, with a minor fraction, $<5 \%$, of
Leistung der Werkzeugstähle im Betrieb verantwortlich war. Heutzutage wird der Begriff Konditionierung von Martensit verwendet, um auf einen isothermen Prozess unbestimmter Natur hinzuweisen, der bei kryogenen Temperaturen stattfindet und der eine Veränderung der Karbidpopulation im Stahl fördert [20].

Im vorigen Abschnitt wurde gezeigt, dass längere Kältebehandlungen bei etwa $-80^{\circ} \mathrm{C}$ eine Erklärung in der isothermen Martensitbildung finden könnten, die bei diesen Temperaturen in bestimmten Stahlsorten optimal abläuft. Konsequenterweise versuchten wir zu verifizieren, ob die isotherme Martensitbildung auch eine Erklärung für die Auswirkung der Haltezeit bei kryogenen Temperaturen auf die Leistung zahlreicher Stähle für Werkzeuge liefern könnte.

Im Jahr 1995 schlugen Zhao und Notis [21] vor, dass die zeitabhängige Martensitbildung in Stahl eher die Regel als die Ausnahme ist: durch Anwendung einer ausreichend hohen Abkühlgeschwindigkeit sollte es immer möglich sein, die Umwandlung von Austenit in Martensit zu unterdrücken. Die Umwandlung würde dann entweder isotherm ablaufen, wenn die Abkühlung bei einer ausreichend hohen Temperatur unterbrochen wird, oder während der Wiedererwärmung. Umgekehrt legt die praktische Erfahrung nahe, dass die Bildung von Martensit in Stahl nicht unterdrückt werden kann, und wenn sie unterdrückt wird, ist sie unter isothermen Bedingungen schwer zu verfolgen. In unseren Laboratorien wurden verschiedene konventionell gehärtete Stahlproben so schnell wie möglich auf $-196^{\circ} \mathrm{C}$ abgekühlt und danach wurde die "isotherme" Martensitbildung, falls vorhanden, während der Erwärmung von $-196^{\circ} \mathrm{C}$ auf Raumtemperatur überwacht. Es wurden isochrone (konstante Erwärmungsrate) Bedingungen angewendet, da solche Tests die Bestimmung einer Aktivierungsenergie der thermisch aktivierten Umwandlung ermöglichen [22], was einen eindeutigen Hinweis auf den Ratenbestimmungsmechanismus gibt. Die Überwachung des Fortschreitens der Martensitbildung wurde wiederum mit Magnetometrie durchgeführt.

Die Beziehung zwischen isothermen und isochronen Untersuchungen ist in Bild 5 dargestellt und zeigt die überlagerten isothermen ZTU- und kontinuierlichen Umwandlungsdiagramme für die Martensitbildung in einem 17-7 PH (AISI 631 Grad: 17Cr-7Ni-1Al0,1C, in Gew.-\%) Edelstahl [23]. Nach dem konventionellen Abschrecken war das Material im Wesentlichen austenitisch, mit einem gerin-

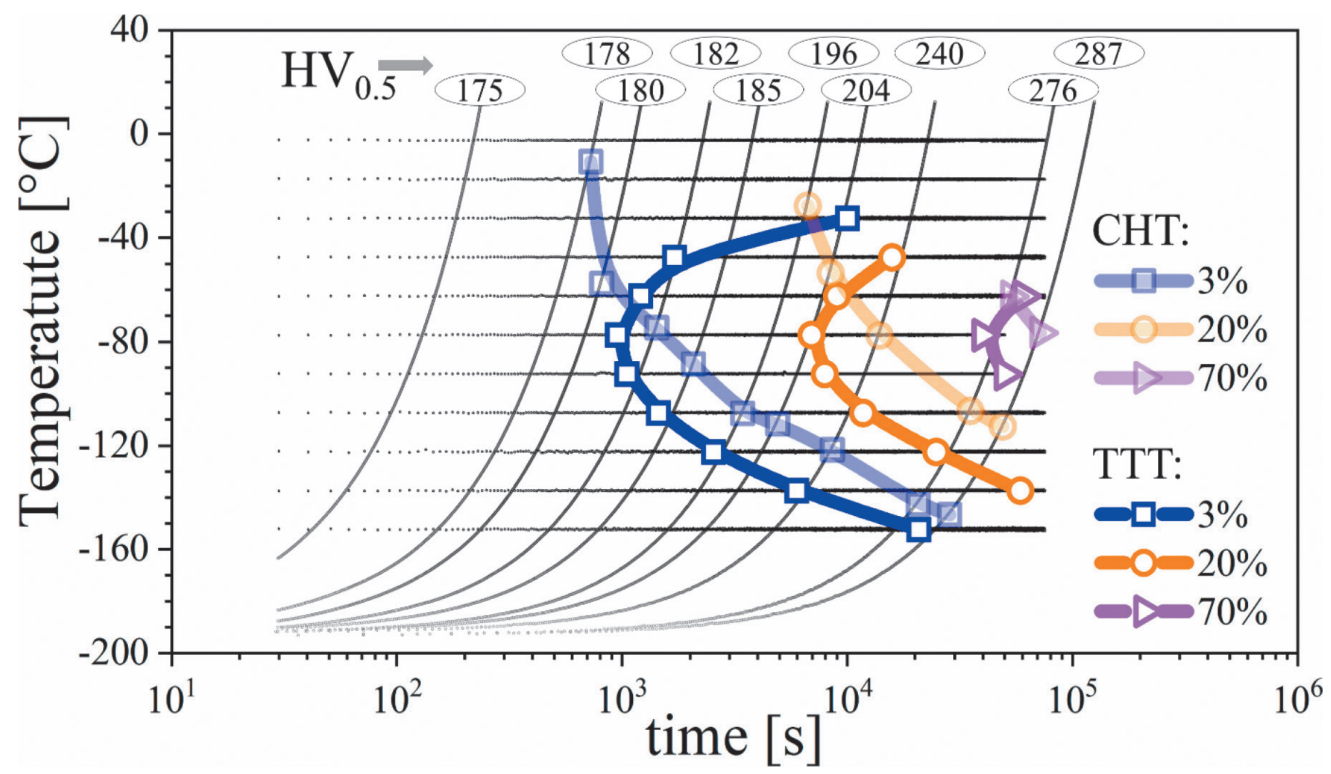

Fig. 5. Superimposed TTT and CHT diagrams for the formation of martensite in 17-7 PH stainless steel. Details of the investigation can be found in [23]

Bild 5. Überlagerte isotherme und kontinuierliche ZTU-Schaubilder für die Bildung von Martensit in rostfreiem Stahl 17-7 PH. Einzelheiten der Untersuchung sind in [23] zu finden 
delta ferrite/martensite. Austenite was fully retained during fast cooling to $-196^{\circ} \mathrm{C}$ by immersion in boiling nitrogen. For the construction of the diagrams, immersion in boiling nitrogen was applied for all samples to guarantee identical starting conditions and was followed by either isothermal investigation at various temperatures (TTT diagram), or isochronal investigation on heating from $-196^{\circ} \mathrm{C}$ to room temperature applying different heating rates (CHT diagram). Figure 5 shows that martensite forms both isothermally as well as during continuous heating (isochronally). The transformation takes place only in the temperature interval $-150{ }^{\circ} \mathrm{C}<\mathrm{T}<-20^{\circ} \mathrm{C}$ : at temperatures below $-150{ }^{\circ} \mathrm{C}$ the transformation could not proceed because of insufficient thermal energy. Above $-20^{\circ} \mathrm{C}$ the driving force for transformation was insufficiently large to outbalance the interfacial and strain energy contributions associated with martensite formation. The TTT diagram shows that, for isothermal treatments, the transformation rate is fastest at approximately $-80{ }^{\circ} \mathrm{C}$. The temperature for maximum transformation rate under isochronal conditions cannot be read from Figure 5. It is shown that this temperature is a function of the heating rate and is shifted to a higher temperature for faster heating. A peculiarity of isochronal conditions reflected in Figure 5 is that the heating rate has a strong effect on the fraction transformed at the end of the sub-zero Celsius cycle. For example, for a heating rate of $15^{\circ} \mathrm{C} / \mathrm{min}$, Figure 5 shows that only $3 \%$ of the RA is converted into martensite, while heating a hundred times slower at $0.15^{\circ} \mathrm{C} / \mathrm{min}$ can convert $70 \%$ of RA. This peculiarity is also manifested in the hardness after completed sub-zero Celsius treatment: the slower the heating, the harder the material at the end of the cycle, reflecting a higher fraction of martensite. The use of hardness as supplementary information shows how CHT diagrams should be imagined, analogous to the well-known Continuous-Cooling-Transformation, CCT, diagrams for the hardening of steel. For example, the isochronal lines in the CHT diagram are shifted to higher temperatures as compared to their corresponding isothermal transformation lines. This is analogous to the shift to lower temperatures observed in CCT diagrams as compared to their corresponding TTT diagrams. Evidently, CHT diagrams would provide useful information for the sub-zero Celsius treatment of steel.

A more complete representation of the isochronal transformation kinetics is obtained by plotting the phase fraction versus temperature. In Figure 6a, f corresponds to the fraction of material revealed by magnetometry as delta ferrite/martensite. The possibility to suppress the austenite-to-martensite transformation during fast cooling to $-196{ }^{\circ} \mathrm{C}$ and, subsequently, fast re-heating to room temperature, is illustrated by horizontal arrows that connect $f$ measured before the cryogenic treatment, after fast cooling to $-196{ }^{\circ} \mathrm{C}$ by immersion in boiling nitrogen and again at $20^{\circ} \mathrm{C}$ after up-quenching in water. The other curves (for the sake of example only two per material in Figure 6) represent the formation of martensite during isochronal heating and show the effect of the heating rate on both the fraction transformed and on the temperature gen Anteil, < 5\%, Delta-Ferrit/Martensit. Der Austenit blieb beim schnellen Abkühlen auf $-196^{\circ} \mathrm{C}$, durch Eintauchen in siedenden Stickstoff, vollständig erhalten. Für die Erstellung der Diagramme wurde das Eintauchen in siedenden Stickstoff für alle Proben angewandt, um identische Ausgangsbedingungen zu gewährleisten, und es folgte entweder eine isotherme Untersuchung bei verschiedenen Temperaturen (isothermes ZTU-Diagramm) oder eine isochronale Untersuchung bei Erwärmung von $-196^{\circ} \mathrm{C}$ auf Raumtemperatur unter Anwendung unterschiedlicher Aufheizraten (kontinuierliches Umwandlungsdiagramm). Bild 5 zeigt, dass sich Martensit sowohl isotherm als auch bei kontinuierlicher Erwärmung (isochron) bildet. Die Umwandlung findet nur im Temperaturintervall $-150^{\circ} \mathrm{C}<\mathrm{T}<-20^{\circ} \mathrm{C}$ statt: bei Temperaturen unter $-150^{\circ} \mathrm{C}$ konnte die Umwandlung wegen zu geringer thermischen Energie nicht ablaufen. Oberhalb von $-20^{\circ} \mathrm{C}$ war die Triebkraft für die Umwandlung nicht groß genug, um die mit der Martensitbildung verbundenen Grenzflächen- und Dehnungsenergiebeiträge auszugleichen. Das ZTU-Schaubild zeigt, dass bei isothermen Behandlungen die Umwandlungsrate bei etwa $-80{ }^{\circ} \mathrm{C}$ am höchsten ist. Die Temperatur für die maximale Umwandlungsrate unter isochronen Bedingungen kann aus Bild 5 nicht abgelesen werden. Es wird gezeigt, dass diese Temperatur eine Funktion der Erwärmungsrate ist und zur schnelleren Erwärmung auf eine höhere Temperatur verschoben wird. Eine Besonderheit der isochronen Bedingungen, die in Bild 5 dargestellt sind, besteht darin, dass die Erwärmungsrate einen starken Einfluss auf den Anteil hat, der am Ende des Unter-Null-Celsius-Zyklus transformiert wird. Beispielsweise zeigt Bild 5 für eine Aufheizrate von $15^{\circ} \mathrm{C} / \mathrm{min}$, dass nur $3 \%$ der RA in Martensit umgewandelt werden, während eine hundertmal langsamere Erwärmung bei $0,15^{\circ} \mathrm{C} / \mathrm{min} 70 \%$ der RA umwandeln kann. Diese Besonderheit zeigt sich auch in der Härte nach abgeschlossener Unter-Null-Celsius-Behandlung: je langsamer die Erwärmung, desto härter ist das Material am Ende des Zyklus, was einen höheren Martensitanteil widerspiegelt. Die Verwendung der Härte als ergänzende Information zeigt, wie man sich kontinuierliche Umwandlungsdiagramme beim Erwärmen vorstellen sollte, analog $\mathrm{zu}$ den bekannten kontinuierlichen ZTU-Diagrammen beim Abkühlen für das Härten von Stahl. Beispielsweise sind die Isochronenlinien im kontinuierlichen Umwandlungsdiagramm im Vergleich zu ihren entsprechenden isothermen Umwandlungslinien zu höheren Temperaturen verschoben. Dies ist analog zu der Verschiebung zu niedrigeren Temperaturen, die in kontinuierlichen ZTU-Diagrammen im Vergleich zu ihren entsprechenden isothermen ZTU-Diagrammen beobachtet wird. Es liegt auf der Hand, dass kontinuierliche Umwandlungsdiagramme beim Erwärmen nützliche Informationen für die Behandlung von Stahl bei Temperaturen unter null Grad Celsius liefern würden.

Eine vollständigere Darstellung der isochronen Transformationskinetik erhält man durch Auftragen des Phasenanteils über der Temperatur. In Bild 6a entspricht $\mathrm{f}$ dem Materialanteil, der durch Magnetometrie als Delta-Ferrit/Martensit ermittelt wurde. Die Möglichkeit, die Austenit-Martensit-Umwandlung während der schnellen Abkühlung auf $-196^{\circ} \mathrm{C}$ und der anschließenden schnellen Wiedererwärmung auf Raumtemperatur zu unterdrücken, wird durch horizontale Pfeile veranschaulicht, die f verbinden, gemessen vor der Tieftemperaturbehandlung, nach der schnellen Abkühlung auf $-196^{\circ} \mathrm{C}$ durch Eintauchen in siedenden Stickstoff und erneut bei $20^{\circ} \mathrm{C}$ nach dem Abschrecken in Wasser. Die anderen Kurven (um des Beispiels willen nur zwei pro Material in Bild 6) stellen die Martensitbildung während der isochronen Erwärmung dar und zeigen 

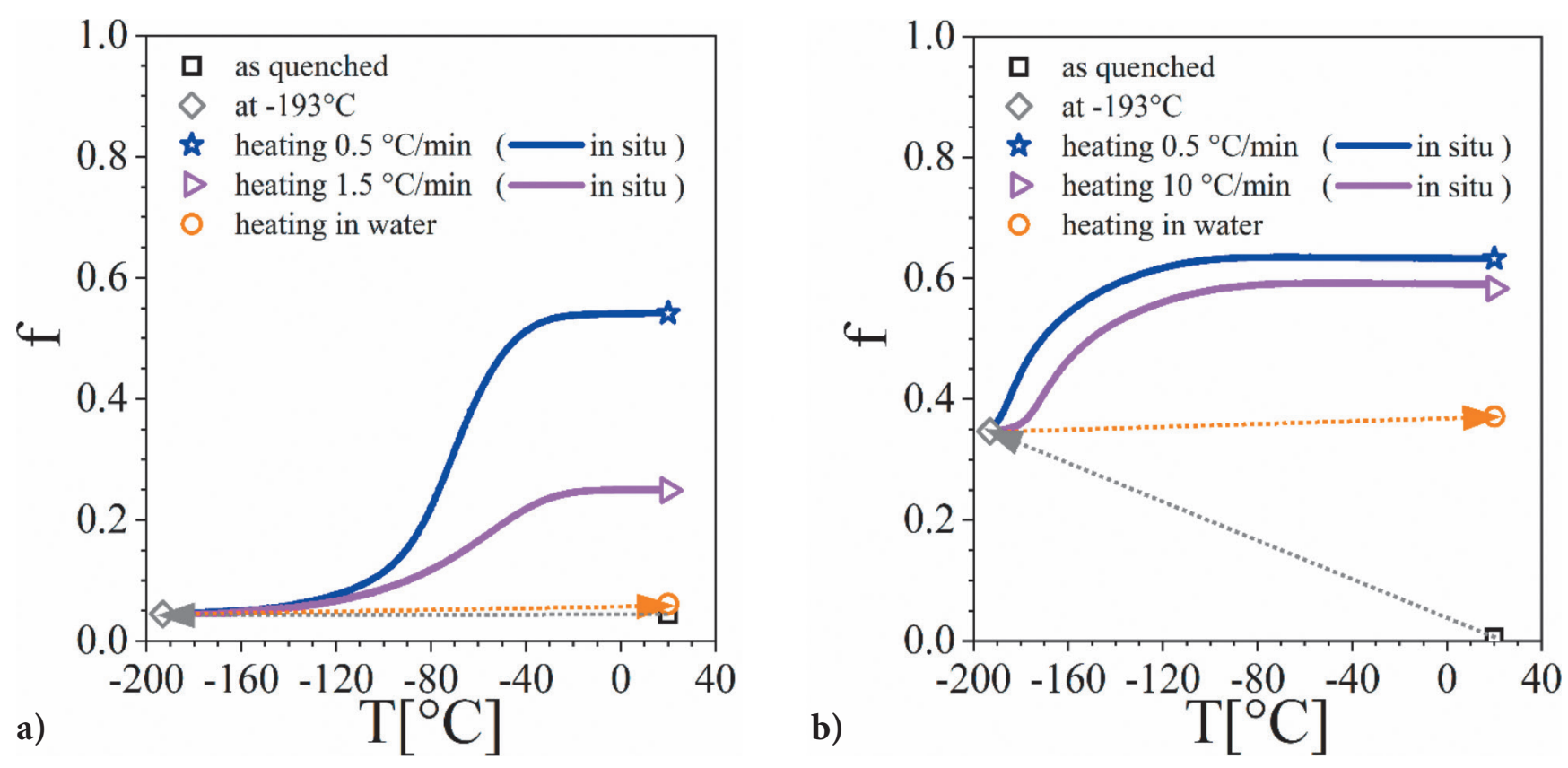

Fig. 6. Fraction of ferromagnetic phase (i.e. martensite + delta ferrite) plotted versus temperature $\mathrm{T}$ for a) a 17-7 PH stainless steel and b) the Fe-17Cr-2Ni$0.4 \mathrm{C}$ alloy. Details of the investigation can be found in $[23,24]$. The initial state of the samples is in the lower right corners from where the materials are quenched to $-196^{\circ} \mathrm{C}$ (gray arrow) on the left-hand side of the graph. From there isochronal heating is applied at different heating rates or up-quenching in water (orange arrow)

Bild 6. Anteil der ferromagnetischen Phase (d. h. Martensit + Delta-Ferrit) aufgetragen gegen die Temperatur T für a) einen rostfreien Stahl mit 17-7 PH und b) die Legierung Fe-17Cr-2Ni-0,4C. Einzelheiten der Untersuchung sind in [23,24] zu finden. Der Anfangszustand der Proben befindet sich in den unteren rechten Ecken, von wo aus die Materialien auf $-196^{\circ} \mathrm{C}$ abgeschreckt werden (grauer Pfeil) auf der linken Seite des Diagramms. Von dort aus erfolgt eine isochrone Erwärmung mit unterschiedlichen Heizraten oder eine Aufwärtsabschreckung in Wasser (oranger Pfeil)

for the highest transformation rate. More importantly, a representation of the transformation as in Figure 6a immediately reveals whether the transformation can be suppressed, or whether it unavoidably takes place.

Figure $6 \mathrm{~b}$ illustrates the evolution of the fraction transformed during sub-zero Celsius treatments for a Fe-17Cr-2Ni-0.4C (in wt.-\%) alloy [24]. This alloy contains a negligible, $<1 \%$, fraction of martensite after quenching to room temperature. For Fe-17Cr-2Ni-0.4C as compared to the $17-7 \mathrm{PH}, \mathrm{Ni}$ is partially substituted by $\mathrm{C}$ to provide a comparable stability of the austenite. This substitution, which appears insignificant, has a huge effect on the kinetics: on immersion in boiling nitrogen, a significant fraction of martensite, approximately $35 \%$, forms instantaneously in Fe-17Cr-2Ni-0.4C, while no transformation occurs in 17-7 PH. Thereafter, the transformation continued during re-heating. The transformation kinetics on heating showed marked differences as well as similarities with the ones reported for the 17-7 PH. For both alloys, the transformation curves are shifted towards relatively low temperatures for the slowest applied heating condition. On the other hand, while the transformation for 17-7 $\mathrm{PH}$ progresses at moderately high temperatures, around $-80^{\circ} \mathrm{C}$, and is non-existent at temperatures lower than $-150^{\circ} \mathrm{C}$, for $\mathrm{Fe}-17 \mathrm{Cr}-2 \mathrm{Ni}-0.4 \mathrm{C}$ alloy the transformation can progress at temperatures approaching $-196^{\circ} \mathrm{C}$, but is negligible at temperatures typically applied in cold treatments (approximately $-80^{\circ} \mathrm{C}$ ). Moreover, up-quenching in water fully suppressed the transformation in 17-7 PH stainless steel, while the transformation in $\mathrm{Fe}-17 \mathrm{Cr}-2 \mathrm{Ni}-0.4 \mathrm{C}$ was minimal, albeit measurable. die Auswirkung der Erwärmungsrate sowohl auf die umgewandelte Fraktion als auch auf die Temperatur für die höchste Umwandlungsrate. Wichtiger ist, dass eine Darstellung der Umwandlung wie in Bild 6a sofort erkennen lässt, ob die Umwandlung unterdrückt werden kann oder ob sie unvermeidlich stattfindet.

Bild 6 b veranschaulicht die Entwicklung der bei Behandlungen unter null Grad Celsius umgewandelten Fraktion für eine $\mathrm{Fe}$ 17Cr-2Ni-0,4C-Legierung (in Gew.-\%) [24]. Diese Legierung enthält nach dem Abschrecken auf Raumtemperatur einen vernachlässigbaren, $<1$ \%igen Anteil Martensit. Bei Fe-17Cr-2Ni0,4C im Vergleich zum 17-7 PH wird Ni teilweise durch C ersetzt, um eine vergleichbare Stabilität des Austenits zu gewährleisten. Diese Substitution, die unbedeutend $\mathrm{zu}$ sein scheint, hat einen großen Einfluss auf die Kinetik: Beim Eintauchen in siedenden Stickstoff bildet sich ein beträchtlicher Anteil des Martensits, etwa 35 \%, sofort in Fe-17Cr-2Ni-0,4C, während bei 17-7 PH keine Umwandlung stattfindet. Danach setzte sich die Umwandlung während der Wiedererwärmung fort. Die Transformationskinetik bei der Erwärmung zeigte deutliche Unterschiede sowie Ähnlichkeiten mit den für die 17-7 PH berichteten. Bei beiden Legierungen sind die Umwandlungskurven für den langsamsten angewandten Erwärmungszustand zu relativ niedrigen Temperaturen hin verschoben. Auf der anderen Seite, während die Umwandlung für 17-7 PH bei mäßig hohen Temperaturen, etwa $-80^{\circ} \mathrm{C}$, fortschreitet und bei Temperaturen unter $-150{ }^{\circ} \mathrm{C}$ nicht vorhanden ist, kann die Umwandlung für die Fe-17Cr-2Ni-0,4C-Legierung bei Temperaturen nahe $-196^{\circ} \mathrm{C}$ fortschreiten, ist aber bei Temperaturen, die typischerweise bei Kaltbehandlungen angewendet werden (etwa $-80^{\circ} \mathrm{C}$ ), vernachlässigbar. Darüber hinaus unterdrückte das $\mathrm{Ab}$ - 
The observation of a significant formation of martensite during cooling to $-196^{\circ} \mathrm{C}$ in $\mathrm{Fe}-17 \mathrm{Cr}-2 \mathrm{Ni}-0.4 \mathrm{C}$ suggests that in this material both the nucleation and the growth of the martensite are, at least partially, athermal and cannot be suppressed. Microscopy (details in the previous paragraph) was applied to obtain information on the athermal and thermally activated parts of the transformation. This time, micrographs were acquired post-mortem and etching was performed on polished samples with Kalling II reagent. Figure 7 shows the micrographs of the microstructures of two samples of $\mathrm{Fe}-17 \mathrm{Cr}-2 \mathrm{Ni}-0.4 \mathrm{C}$ : one immersed in boiling nitrogen and re-heated to room temperature in water (up-quenched); the other immersed in boiling nitrogen and re-heated at $1{ }^{\circ} \mathrm{C} / \mathrm{min}$. As shown in Figure 6b, in the sample that was up-quenched in water, almost all martensite formed athermally during cooling, while in the sample subjected to controlled slow heating an appreciable fraction of the martensite, approximately $25 \%$, forms after thermal activation during heating. Figure 7 illustrates that the athermal martensite formed in practically all (prior) austenite grains.

The martensite morphology is "thin plate" and a planar boundary martensite/austenite exists. Thermal activation during re-heating promoted the formation of a large number of additional martensite plates. Moreover, the morphology evolved from thin plates with planar interface with austenite, to thick plates with a lenticular aspect, indicating that growth of the plate is partially of thermally activated character.

The type of investigation presented in Figure 6 was repeated for various alloys, including a few $\mathrm{Fe}-\mathrm{N}$ and $\mathrm{Fe}-\mathrm{C}$ binary alloys, several Fe-Cr-C and Fe-Cr-Ni-C steels, 15-7 PH, 17-7 PH and Nanoflex ${ }^{\circledast}$ maraging stainless steel (12Cr-9Ni-5Mo-2Cu-1Ti in wt.- $\%)$ and a Fe-Cr-Ni model alloy with extra-low interstitial content. In all cas- schrecken in Wasser die Umwandlung in rostfreiem Stahl 17-7 PH vollständig, während die Umwandlung in $\mathrm{Fe}-17 \mathrm{Cr}-2 \mathrm{Ni}-0,4 \mathrm{C}$ minimal, wenn auch messbar war.

Die Beobachtung einer signifikanten Martensitbildung während der Abkühlung auf $-196{ }^{\circ} \mathrm{C}$ in $\mathrm{Fe}-17 \mathrm{Cr}-2 \mathrm{Ni}-0,4 \mathrm{C}$ deutet darauf hin, dass in diesem Material sowohl die Keimbildung als auch das Wachstum des Martensits zumindest teilweise athermisch sind und nicht unterdrückt werden können. Um Informationen über den athermischen und den thermisch aktivierten Teil der Umwandlung zu erhalten, wurde die Mikroskopie (Einzelheiten im vorigen Absatz) angewandt. Diesmal wurden die Schliffbilder post mortem aufgenommen und die Ätzung wurde an polierten Proben mit Kalling II-Reagenz durchgeführt. Bild 7 zeigt die Schliffbilder der Gefüge von zwei Proben von Fe-17Cr-2Ni-0,4C: eine in siedenden Stickstoff getaucht und in Wasser auf Raumtemperatur erwärmt (,aufgeschreckt“); die andere in siedenden Stickstoff getaucht und bei $1^{\circ} \mathrm{C} / \mathrm{min}$ wieder erwärmt. Wie in Bild $6 \mathrm{~b}$ gezeigt, bildete sich in der Probe, die in Wasser aufgeschreckt wurde, fast der gesamte Martensit während des Abkühlens athermisch, während sich in der Probe, die einer kontrollierten langsamen Erwärmung unterzogen wurde, nach der thermischen Aktivierung während des Erwärmens ein beträchtlicher Anteil des Martensits, etwa $25 \%$, bildet. Bild 7 zeigt, dass sich der athermische Martensit in praktisch allen (früheren) Austenitkörnern gebildet hat.

Die Morphologie des Martensits besteht aus dünnen Platten und es existiert eine planare Grenzfläche Martensit/Austenit. Die thermische Aktivierung während der Wiedererwärmung förderte die Bildung einer großen Anzahl von zusätzlichen Martensitplatten. Darüber hinaus entwickelte sich die Morphologie von dünnen Platten mit einer planaren Grenzfläche mit Austenit zu dicken Platten mit einem linsenförmigen Aspekt, was darauf hinweist, dass das Wachstum der Platte teilweise thermisch aktivierten Charakter hat.

Die in Bild 6 dargestellte Art der Untersuchung wurde für verschiedene Legierungen wiederholt, darunter einige binäre $\mathrm{Fe}-\mathrm{N}$ und Fe-C-Legierungen, mehrere Fe-Cr-C- und Fe-Cr-Ni-C-Stähle, 15-7 PH, 17-7 PH und Nanoflex ${ }^{ø}$ martensitaushärtender Edelstahl (12Cr-9Ni-5Mo-2Cu-1Ti in Gew.-\%) und eine Fe-Cr-Ni-Modellle-
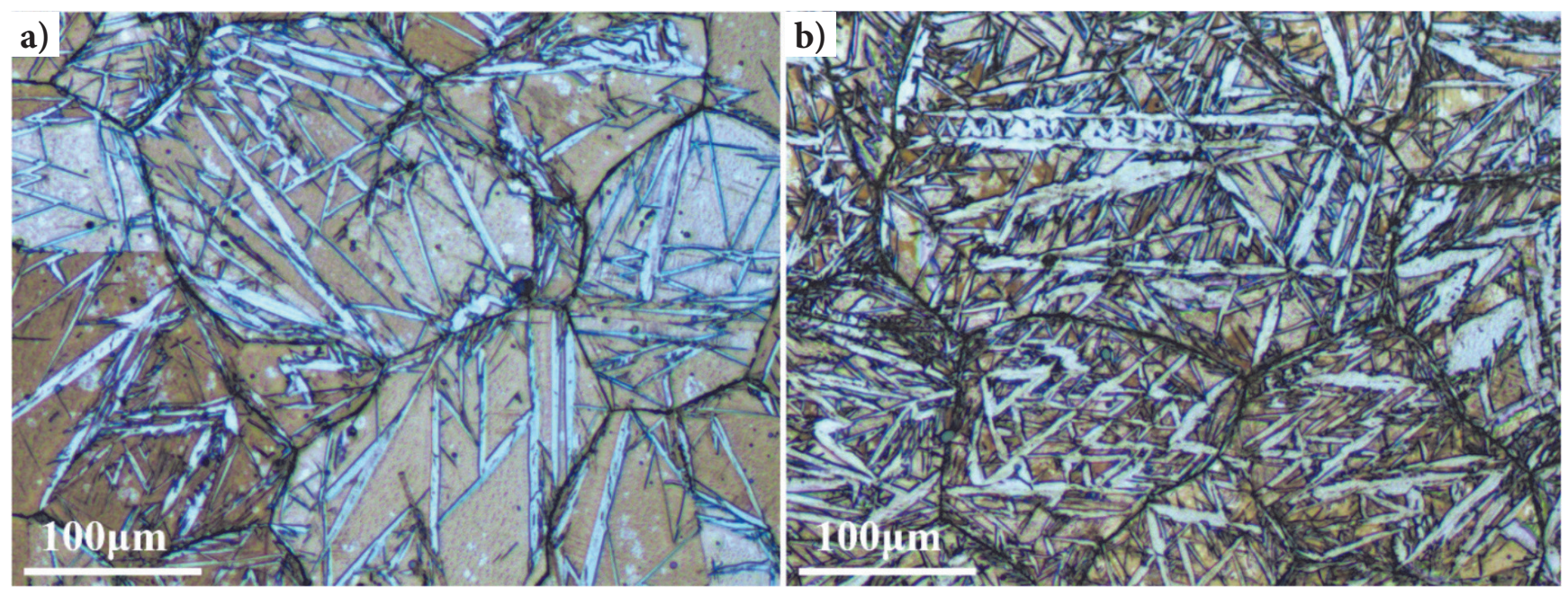

Fig. 7. Micrographs of $17 \% \mathrm{Cr}-2 \% \mathrm{Ni}-0.4 \% \mathrm{C}$ steel subjected to sub-zero Celsius treatment that illustrate the difference between athermal martensite (a) and the evolution of its morphology upon thermally activated growth (b)

Bild 7. Schliffbilder von $17 \% \mathrm{Cr}-2 \% \mathrm{Ni}-0,4 \% \mathrm{C}-$ Stahl, der einer Behandlung unter Null Grad Celsius unterzogen wurde, die den Unterschied zwischen athermischem Martensit (a) und der Entwicklung seiner Morphologie bei thermisch aktiviertem Wachstum (b) veranschaulichen 
es, the materials were treated to a fully austenitic condition prior to hardening to room temperature. Sub-zero Celsius treatment consisted in cooling to $-196^{\circ} \mathrm{C}$ by immersion in boiling nitrogen followed by isochronal heating at various rates in the range $0.1-$ $120^{\circ} \mathrm{C} / \mathrm{min}$. A summary of the materials, chemistry, of the fraction transformed versus applied sub-zero Celsius treatment and of other important aspects (see below) of the martensitic transformation in the various alloys are reported in Table 1. Details on the chemical composition of the various materials and on the thermal histories can be found elsewhere together with several of the transformation curves [24-26]. As indicated in Table 1, the investigation reveals that ferrous alloys can be subdivided in two groups. These are characterized by transformation kinetics exemplified in Figure $6 \mathrm{a}$ and $6 \mathrm{~b}$, respectively. In materials belonging to group I, essentially $\mathrm{PH}$ and maraging stainless steels, martensite formation could be (almost) completely suppressed by fast cooling to $-196^{\circ} \mathrm{C}$ as well as by fast re-heating to room temperature. An increase of the fraction transformed was only possible at temperatures higher than $-150^{\circ} \mathrm{C}$. In materials belonging to group II, which is the large majority of ferrous alloys with a significant fraction of RA, not all martensite formation could be suppressed by fast cooling. Martensite formation, including the formation of isothermal martensite, was possible down to cryogenic temperatures.

In conclusion, the data indicates that martensite formation can explain a (positive) effect of both the reduction of the treatment temperature down to cryogenic temperatures, as well as of the increase of the holding time at such temperatures, on the performance of gierung mit extra niedrigem interstitiellen Gehalt. In allen Fällen wurden die Werkstoffe vor der Aushärtung auf Raumtemperatur in einen vollständig austenitischen Zustand gebracht. Die Behandlung bei Temperaturen unter null Grad Celsius bestand aus einer Abkühlung auf $-196^{\circ} \mathrm{C}$ durch Eintauchen in siedenden Stickstoff, gefolgt von isochroner Erwärmung mit verschiedenen Geschwindigkeiten im Bereich von $0,1-120^{\circ} \mathrm{C} / \mathrm{min}$. Eine Zusammenfassung der Materialchemie, der umgewandelten Fraktion im Vergleich zur angewandten Unter-Null-Celsius-Behandlung und anderer wichtiger Aspekte (siehe unten) der martensitischen Umwandlung in den verschiedenen Legierungen ist in Tabelle 1 dargestellt. Einzelheiten zur chemischen Zusammensetzung der verschiedenen Werkstoffe und zu den thermischen Vorgängen sind zusammen mit einigen der Umwandlungskurven an anderer Stelle zu finden [24-26]. Wie in Tabelle 1 angegeben, zeigt die Untersuchung, dass sich Eisenlegierungen in zwei Gruppen unterteilen lassen. Diese sind durch eine Transformationskinetik gekennzeichnet, die in Bild 6a bzw. $6 \mathrm{~b}$ beispielhaft dargestellt ist. In Werkstoffen der Gruppe I, im Wesentlichen PH- und martensitaushärtende Edelstähle, konnte die Martensitbildung durch schnelles Abkühlen auf $-196^{\circ} \mathrm{C}$ sowie durch schnelles Wiedererwärmen auf Raumtemperatur (fast) vollständig unterdrückt werden. Eine Erhöhung des umgewandelten Anteils war erst bei Temperaturen über $-150^{\circ} \mathrm{C}$ möglich. In Werkstoffen der Gruppe II, die die große Mehrheit der Eisenlegierungen mit einem signifikanten Anteil an RA ausmachen, konnte die Martensitbildung durch schnelles Abkühlen nicht vollständig unterdrückt werden. Martensitbildung, einschließlich der Bildung von isothermem Martensit, war bis hinunter zu kryogenen Temperaturen möglich.

Zusammenfassend deuten die Daten darauf hin, dass die Martensitbildung einen (positiven) Effekt auf die Leistung von Stahlteilen, die einer Behandlung unter null Grad Celsius unterzogen wurden, erklären kann. Tatsächlich kann sowohl die Abkühlung

\begin{tabular}{|c|c|c|c|c|c|}
\hline Chemistry (wt.-\%) & Kinetics Group & $f$ start & $f$ athermal & $f$ th. activated & Type of martensite \\
\hline Fe-2.2N & II & $1 \%$ & $37 \%$ & $14 \%$ & $\{259\}_{\gamma}$ \\
\hline Fe-1.8N & II & $32 \%$ & $30 \%$ & $15 \%$ & $\{259\}_{\gamma}$ \\
\hline Fe-1.6C & II & $57 \%$ & $29 \%$ & $4 \%$ & $\{259\}_{\gamma}$ \\
\hline Fe-1.2C & II & $81 \%$ & $13 \%$ & $3 \%$ & $\{225\}_{\gamma}$ \\
\hline Fe-1C & II & $89 \%$ & $6 \%$ & $3 \%$ & $\{225\}_{\gamma}$ \\
\hline Fe-1.5Cr-1C & II & $59 \%$ & $21 \%$ & $6 \%$ & $\{259\}_{\gamma}$ \\
\hline Fe-12Cr-0.7C & II & $5 \%$ & $61 \%$ & $11 \%$ & $\{31015\}_{\gamma} /\{259\}_{\gamma}$ \\
\hline Fe-17Cr-2Ni-0.4C & II & $1 \%$ & $37 \%$ & $14 \%$ & $\{557\}_{\gamma}+\{259\}_{\gamma}$ \\
\hline Fe-17Cr-2Ni-0.2C & II & $16 \%$ & $47 \%$ & $1 \%$ & $\{557\}_{\gamma}$ \\
\hline $15-7 P H$ & I & $13 \%$ & $1 \%$ & $49 \%$ & $\{557\}_{\gamma}$ \\
\hline $17-7 P H$ & I & $4 \%$ & $0 \%$ & $12 \%$ & $\{557\}_{\gamma}$ \\
\hline Nanoflex & I & $79 \%$ & $21 \%$ & 6 & $\{112\}_{\gamma}$ \\
\hline Fe-15Cr-13Ni & II & $0 \%$ & & & \\
\hline
\end{tabular}

Table 1. Investigated alloys and characteristics of the martensite formation observed within various alloys. f start indicates the fraction of martensite/ferrite at the beginning of the investigation. $\mathrm{f}$ athermal indicates the fraction of martensite that formed during fast cooling to $-196^{\circ} \mathrm{C}$ followed by up-quenching in water. $f$ thermally activated indicates the additional fraction of martensite formed upon slow isochronal heating at $3^{\circ} \mathrm{C} / \mathrm{min}$ for $\mathrm{Fe}-15 \mathrm{Cr}-13 \mathrm{Ni}$ and $0.5^{\circ} \mathrm{C} / \mathrm{min}$ for all other alloys

Tabelle 1. Untersuchte Legierungen und Charakteristika der Martensitbildung, die in verschiedenen Legierungen beobachtet wurde. f start gibt den Anteil Martensit/Ferrit zu Beginn der Untersuchung an. $f$ athermal gibt den Anteil Martensit an, der sich beim schnellen Abkühlen auf $-196^{\circ} \mathrm{C}$ mit anschließendem Aufschrecken in Wasser gebildet hat. $f$ thermisch aktiviert gibt den zusätzlichen Anteil Martensit an, der sich bei langsamer isochroner Erwärmung bei $3^{\circ} \mathrm{Cl}$ min für $\mathrm{Fe}-15 \mathrm{Cr}-13 \mathrm{Ni}$ und $0,5^{\circ} \mathrm{C} / \mathrm{min}$ für alle anderen Legierungen gebildet hat 
steel parts subjected to sub-zero Celsius treatment. In fact, both cooling to $-196^{\circ} \mathrm{C}$ and isothermal holding at this temperature for a very long time can promote the formation of a significant fraction of martensite in steel. This conclusion does not exclude the possibility that additional (diffusionless) mechanisms could take place during the cryogenic treatment of steels and be of fundamental importance in affecting their performance. Nevertheless, it is now firmly established that it is not necessary to invoke such additional mechanisms (for example martensite conditioning) in order to explain the results of, among others, Barron and co-workers. Martensite formation in steels occurs during cooling, heating and isothermal holding. To understand the effect of martensite formation on steel performance, it is evident that tailoring of cryogenic treatment for various steel grades requires additional understanding of the transformation mechanisms. Subdivision of martensitic transformations in group I and group II as above could rationalize this. In order to arrive at a consistent interpretation of all data, it is further necessary to address the morphological features of martensite. In the next paragraph, this is done based on the martensite morphology and the internal structure in martensite as well-documented in the scientific literature.

\section{Suppressible vs insuppressible martensite: a new paradigm for martensite formation in steel}

Ferrous b.c.c./b.c.t. martensites have different morphological and substructure features associated with their habit plane (HP) in the parent austenite [27, 28]. The HPs observed in ferrous systems are classified according to the approximate crystallographic planes in the f.c.c. crystal as $\left.\left\{\begin{array}{llll}3 & 10 & 15\end{array}\right\}_{\gamma}\left\{\begin{array}{llll}2 & 5 & 9\end{array}\right\}_{\gamma}\left\{\begin{array}{llll}2 & 2 & 5\end{array}\right\}_{\gamma}, \begin{array}{lllll}5 & 5 & 7\end{array}\right\}_{\gamma}$ and $\left\{\begin{array}{llll}1 & 1 & 2\end{array}\right\}_{\gamma}$. The different types of martensite are further subdivided in plate martensite and lath martensite $[29,30]$.

$\left\{\begin{array}{llll}3 & 10 & 15\end{array}\right\}_{\gamma}$ plate martensite presents a thin plate morphology. Thin plate martensite is characterized by a smooth planar interface with the parent austenite and by the presence of twins inside the martensite, that extend from one interface to the other [28]. Such an interface is glissile implying that it can easily move, and thereby complies with an athermal transformation. For this type of martensite the volume change associated with its formation is accommodated entirely elastically in the austenite [31]. The combination of a twinned internal structure within martensite and the glissile interface allows this martensite to form (i. e. nucleate and grow) at a temperature as low $-269^{\circ} \mathrm{C}[32,33]$. The formation of thin plate martensite progressively partitions the austenite grains, so that the retained austenite shows polygonal morphology and the transformation hardly approaches completion. A typical example of thin plate martensite is shown in Figure 7a. auf $-196^{\circ} \mathrm{C}$ als auch das isotherme Halten bei dieser Temperatur über einen sehr langen Zeitraum die Bildung eines signifikanten Anteils von Martensit im Stahl fördern. Diese Schlussfolgerung schließt die Möglichkeit nicht aus, dass zusätzliche (diffusionslose) Mechanismen während der Tieftemperaturbehandlung von Stählen stattfinden und von grundlegender Bedeutung für die Beeinflussung ihrer Leistung sein könnten. Nichtsdestotrotz steht jetzt fest, dass es nicht notwendig ist, solche zusätzlichen Mechanismen (z. B. Martensit-Konditionierung) geltend zu machen, um die Ergebnisse u. a. von Barron und seinen Mitarbeitenden zu erklären. Die Martensitbildung in Stählen tritt beim Abkühlen, Erhitzen und isothermischen Halten auf. Um die Auswirkung der Martensitbildung auf die Stahlleistung zu verstehen, ist es offensichtlich, dass die Anpassung der Tieftemperaturbehandlung für verschiedene Stahlsorten ein zusätzliches Verständnis der Umwandlungsmechanismen erfordert. Eine Unterteilung der martensitischen Umwandlungen in Gruppe I und Gruppe II, wie zuvor beschrieben, könnte dies rationalisieren. Um zu einer konsistenten Interpretation aller Daten zu gelangen, ist es ferner notwendig, sich mit den morphologischen Merkmalen des Martensits zu befassen. Im nächsten Abschnitt geschieht dies auf der Grundlage der Martensitmorphologie und der internen Struktur im Martensit, die in der wissenschaftlichen Literatur gut dokumentiert sind.

\section{Unterdrückbarer vs. nicht unterdrück- barer Martensit: ein neues Paradigma für die Martensitbildung in Stahl}

Eisenhaltiger k.r.z/t.r.z.-Martensit ${ }^{1}$ weist unterschiedliche morphologische und Substruktureigenschaften auf, die mit ihrer Habitusebene (HP) im Ausgangsaustenit assoziiert sind [27, 28]. Die in eisenhaltigen Systemen beobachteten Habitusebenen werden entsprechend den ungefähren kristallographischen Ebenen im k.f.z.Kristall $^{2}$ als $\left\{\begin{array}{lllll}3 & 10 & 15\end{array}\right\}_{\gamma}\left\{\begin{array}{llll}2 & 5 & 9\end{array}\right\}_{\gamma},\left\{\begin{array}{llll}2 & 2 & 5\end{array}\right\}_{\gamma},\left\{\begin{array}{llll}5 & 5 & 7\end{array}\right\}_{\gamma}$ und $\left\{\begin{array}{llll}1 & 1 & 2\end{array}\right\}_{\gamma}$ klassifiziert. Die verschiedenen Martensittypen werden weiter in Plattenmartensit und Lattenmartensit unterteilt [29, 30].

$\left\{\begin{array}{lll}3 & 10 & 15\end{array}\right\}_{\gamma}$-Plattenmartensit weist eine dünne Plattenmorphologie auf. Dünnplatten-Martensit ist durch eine glatte planare Grenzfläche mit dem Ausgangsaustenit und durch das Vorhandensein von Zwillingen innerhalb des Martensits gekennzeichnet, die sich von einer Grenzfläche zur anderen erstrecken [28]. Eine solche Grenzfläche ist glissil (gleitfähig), was bedeutet, dass sie sich leicht bewegen kann und damit einer athermischen Umwandlung entspricht. Bei dieser Art von Martensit wird die mit seiner Bildung verbundene Volumenänderung vollständig elastisch im Austenit untergebracht [31]. Die Kombination einer verzwillingten inneren Struktur innerhalb des Martensits und der gleitfähigen Grenzfläche ermöglicht die Bildung (d. h. Keimbildung und Wachstum) dieses Martensits bei einer Temperatur von bis $\mathrm{zu}-269^{\circ} \mathrm{C}[32,33]$. Die Bildung von dünnem Plattenmartensit teilt die Austenitkörner allmählich auf, sodass der Restaustenit eine polygonale Morphologie aufweist und die Umwandlung sich kaum dem Abschluss nähert. Ein typisches Beispiel für Dünnplattenmartensit ist in Bild 7a dargestellt. 
$\{259\}_{\gamma}$ plate martensite has a lenticular morphology. Lenticular martensite nucleates as thin plate martensite and develops into a lenticular shape on subsequent growth [34-37]. Different stages of growth that lead to the lenticular morphology are reflected by the presence of an internally twinned midrib, the original thin plate. This midrib is surrounded by a twinned region and finally by a fragmented peripheral area in which the internal structure consists of dislocations. When the slipped (dislocated) region is present, the austenite-to-martensite interface is irregular. Moreover, the interface was claimed sessile, implying that it requires thermal activation to move [38]. The volume change associated with partially slipped lenticular martensite is accommodated plastically in the austenite [39]. Reference [34] indicated that the evolution of thin plate martensite into partially slipped lenticular martensite is thermally activated. Partially slipped lenticular martensite can form fast at a temperature higher than $-150^{\circ} \mathrm{C}[40,35]$ while its formation requires numerous hours at $-196{ }^{\circ} \mathrm{C}$ [34]. Plastic deformation can promote the formation of fully internally twinned lenticular martensite at $-269^{\circ} \mathrm{C}$ [40]. A typical example of lenticular martensite can be visualized in Figure 7b. Note that this martensite morphology developed from thin plate martensite (Figure 7a) upon slow heating to room temperature, allowing its thermally activated formation.

$\left\{\begin{array}{lll}2 & 2 & 5\end{array}\right\}_{\gamma}$ martensite can manifest as butterfly as well as plate morphology. In both cases, the austenite-to-martensite interface can be smooth as well as highly irregular and the substructure can be fully internally twinned or fully composed of highly slipped/dislocated areas [27, 28]. Ref.[41] suggested that $\left.\begin{array}{llll}2 & 2 & 5\end{array}\right\}_{\gamma}$ martensite nucleates in the shape of small fully internally twinned $\left\{\begin{array}{lll}2 & 2 & 5\end{array}\right\}_{\gamma}$ plates and that growth of these plates is time dependent. The formation of $\left\{\begin{array}{lll}2 & 2 & 5\end{array}\right\}_{\gamma}$ martensite generates a large number of defects in the surrounding austenite [41-43], which reveals plastic accommodation. There is experimental evidence of martensite formation at $-269^{\circ} \mathrm{C}$ in systems characterized by the formation of $\left\{\begin{array}{lll}2 & 25\end{array}\right\}_{\gamma}$ martensite $[44,45]$. Martensite of the $\{225\}_{\gamma}$ type that forms at $\mathrm{T} \leq-196^{\circ} \mathrm{C}$ is fully internally twinned [46].

The $\left\{\begin{array}{l}5 \\ 57\end{array}\right\}_{\gamma}$ lath martensite, also named massive martensite [30], appears as laths with a substructure characterized by a high density of dislocations [27, 47]. The laths are distributed in a hierarchical microstructure [30, 48-50]. Firstly, the austenite grains are divided into groups of laths with the same habit plane, so-called packets. Each packet contains several blocks, which are groups of laths with one or two coupled variants of the orientation relationship with the parent austenite. The individual laths represent the smallest level of sub-division. The formation of $\{557\}_{\gamma}$ martensite is accommodated plastically in austenite [31] and the structure of its interface with the parent phase [51] was claimed identical to the one observed for the peripheral region of lenticular martensite (i. e. sessile) [38]. The lowest temperature at which the formation of $\{557\}_{\gamma}$ martensite has been reported is $-190^{\circ} \mathrm{C}$ in [52]. An example of the surface relieve associated with the formation of
$\{259\}_{\gamma}$-Plattenmartensit hat eine linsenförmige Morphologie. Linsenförmige Martensit keimbildet als Dünnplattenmartensit und entwickeln sich beim nachfolgenden Wachstum zu einer linsenförmigen Gestalt [34-37]. Die verschiedenen Wachstumsstadien, die zu der linsenförmigen Morphologie führen, spiegeln sich im Vorhandensein einer intern verzwillingten Mittelrippe, der ursprünglichen dünnen Platte, wider. Diese Mittelrippe ist von einer verzwillingten Region und schließlich von einem fragmentierten peripheren Bereich umgeben, in dem die innere Struktur aus Versetzungen besteht. Wenn der verrutschte (versetzungsreiche) Bereich vorhanden ist, ist die Austenit-Martensit-Grenzfläche unregelmäßig. Darüber hinaus wurde behauptet, die Grenzfläche sei sessil, was impliziert, dass sie eine thermische Aktivierung erfordert, um sich zu bewegen [38]. Die mit dem teilweise verrutschten linsenförmigen Martensit verbundene Volumenänderung wird plastisch im Austenit untergebracht [39]. In Referenz [34] wurde angegeben, dass die Entwicklung von Dünnplattenmartensit zu teilweise gerutschtem linsenförmigen Martensit thermisch aktiviert wird. Teilweise gleitender linsenförmiger Martensit kann sich bei einer Temperatur von mehr als $-150^{\circ} \mathrm{C}$ schnell bilden [40, 35], während seine Bildung bei $-196^{\circ} \mathrm{C}$ mehrere Stunden dauert [34]. Eine plastische Verformung kann die Bildung von vollständig innen verzwillingten Linsenmartensit bei $-269^{\circ} \mathrm{C}$ fördern [40]. Ein typisches Beispiel von linsenförmigem Martensit ist in Bild $7 \mathrm{~b}$ dargestellt. Es ist zu beachten, dass sich diese Martensitmorphologie bei langsamer Erwärmung auf Raumtemperatur aus Dünnplatten-Martensit (Bild 7a) entwickelt hat, was seine thermisch aktivierte Bildung ermöglicht.

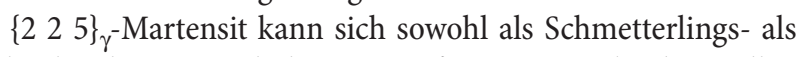
auch als Plattenmorphologie manifestieren. In beiden Fällen kann die Austenit-Martensit-Grenzfläche sowohl glatt als auch sehr unregelmäßig sein, und der Unterbau kann vollständig intern verzwillingt sein oder vollständig aus stark verrutschten/ versetzungsreiche Bereichen bestehen [27, 28]. Referenz [41] schlug vor, dass $\left\{\begin{array}{lll}2 & 2 & 5\end{array}\right\}_{\gamma}$-Martensitkerne in Form von kleinen, vollständig innen verzwillingten $\left\{\begin{array}{lll}2 & 2 & 5\end{array}\right\}_{\gamma}$-Platten entstehen und dass das Wachstum dieser Platten zeitabhängig ist. Die Bildung von $\left\{\begin{array}{lll}2 & 2 & 5\end{array}\right\}_{\gamma}$-Martensit erzeugt eine große Anzahl von Defekten im umgebenden Austenit [41-43], was eine plastische Akkommodation erkennen lässt. Es gibt experimentelle Beweise für die Martensitbildung bei $-269^{\circ} \mathrm{C}$ in Systemen, die durch die Bildung von $\left\{\begin{array}{lll}2 & 2 & 5\end{array}\right\}_{\gamma}$ Martensit gekennzeichnet sind [44, 45]. Martensit des Typs $\{225\}_{\gamma}$, der sich bei $\mathrm{T} \leq-196^{\circ} \mathrm{C}$ bildet, ist vollständig intern verzwillingt [46].

Der Lattenmartensit $\{557\}_{\gamma}$, auch massiver Martensit genannt [30], erscheint als Latten mit einem Interstruktur, der sich durch eine hohe Versetzungsdichte auszeichnet [27, 47]. Die Latten sind in einer hierarchischen Mikrostruktur verteilt [30, 48-50]. Zunächst werden die Austenitkörner in Gruppen von Latten mit der gleichen Habitusebene, sogenannte Pakete, unterteilt. Jedes Paket enthält mehrere Blöcke, d. h. Gruppen von Latten mit einer oder zwei gekoppelten Varianten der Orientierungsbeziehung mit dem Ausgangsaustenit. Die einzelnen Latten stellen die kleinste Ebene der Unterteilung dar. Die Bildung von $\{557\}_{\gamma}$-Martensit ist plastisch im Austenit untergebracht [31] und die Struktur seiner Grenzfläche mit der Mutterphase [51] wurde als identisch mit der für die periphere Region des linsenförmigen Martensits (d. h. sessil) beobachteten [38] beansprucht. Die niedrigste Temperatur, bei der die Bildung von $\{557\}_{\gamma}$-Martensit beobachtet wurde, beträgt 
$\left\{\begin{array}{lll}5 & 5 & 7\end{array}\right\}_{\gamma}$ lath martensite can be observed in Figure 4. $\left\{\begin{array}{lll}1 & 1 & 2\end{array}\right\}_{\gamma}$ lath martensite appears as groups of laths confined within bands of either $\left\{\begin{array}{lll}1 & 1 & 1\end{array}\right\}_{\gamma}$ stacking faults or $\left\{\begin{array}{lll}1 & 1 & 1\end{array}\right\}_{\gamma}$ plates of martensite with hexagonal crystal structure, so called $\varepsilon$ martensite [53]. The substructure of the $\alpha$ ' martensite is composed of areas with high dislocation density (i. e. slipped martensite). The $\left\{\begin{array}{lll}1 & 1 & 2\end{array}\right\}_{\gamma}$ martensite can form at $-269^{\circ} \mathrm{C}[32,54-57]$ and its formation can promote the generation of additional $\left\{\begin{array}{lll}1 & 1 & 1\end{array}\right\}_{\gamma}$ planar defects in austenite [53]. Like the case of $\left\{\begin{array}{lll}3 & 10 & 15\end{array}\right\}_{\gamma}$ thin plate martensite, the spontaneous formation of $\left\{\begin{array}{lll}1 & 1 & 2\end{array}\right\}_{\gamma}$ martensite hardly approaches completion. This is due to the fact that the $\left\{\begin{array}{llll}1 & 1 & 1\end{array}\right\}_{\gamma}$ bands progressively partition the austenite grains during transformation [58].

The materials listed in Table 1 represent all of the above types of martensite. The steels/alloys classified as group I are the ones that develop $\left\{\begin{array}{ll}5 & 5\end{array} 7\right\}_{\gamma}$, i. e. massive, martensite. Evidently, the formation of massive martensite can be suppressed by fast cooling to boiling nitrogen temperature as well as on up-quenching, in contrast to all other types of martensite (group II). In fact, with the exception of $\{557\}_{\gamma}$, it has been shown for all other types of martensite, that the transformation can occur at $-269^{\circ} \mathrm{C}[32,33,40,44,45,54-57]$. Interestingly, it was previously demonstrated that during hardening of pure $\mathrm{Fe}$, the formation of massive martensite can be suppressed by applying extremely high cooling rates [59-61]. In this case, the austenite transforms into a partially twinned product identified as $\left\{\begin{array}{lll}2 & 2 & 5\end{array}\right\}_{\gamma}$ martensite at an approximately $130{ }^{\circ} \mathrm{C}$ lower temperature, $420^{\circ} \mathrm{C}$ instead of $550{ }^{\circ} \mathrm{C}$. Evidently, the conclusion that the formation of massive martensite can be suppressed by fast cooling is not prerogative of sub-zero Celsius treatment, but it is rather general. Additionally, the $\left\{\begin{array}{l}557 \\ 7\end{array}\right\}_{\gamma}$ martensite and the peripheral region of lenticular martensite share the substructure and the structure of the interface with the parent austenite. Hence, these products are essentially identical. Evidently, suppressible martensite can exist as $\{557\}_{\gamma}$ lath martensite, as the dislocated martensite growing on $\left\{\begin{array}{lll}3 & 10 & 15\end{array}\right\}_{\gamma}$ thin plates which promotes the evolution into $\left\{\begin{array}{lll}2 & 5 & 9\end{array}\right\}_{\gamma}$ lenses, and as the martensite growing on twinned $\left\{\begin{array}{lll}2 & 2 & 5\end{array}\right\}_{\gamma}$ units, which promotes thickening. In 1966, Huizing and Klostermann were the first to suggest this rationalization [62]. On the other side there is insuppressible martensite, which corresponds to all the internally twinned martensitic products and to the slipped martensite of $\left\{\begin{array}{lll}1 & 1 & 2\end{array}\right\}_{\gamma}$ type. It is important to remark that insuppressible is not synonymous to "independent of time", or athermal. Isothermal nucleation of insuppressible martensite can take place also at $-269^{\circ} \mathrm{C}$ and was extensively studied by others $[63,64]$.

In Figure 8 we propose a schematic diagram to illustrate the above rationalization of martensite formation in steel. Massive martensite is presented in terms of a $\mathrm{C}$-curve to indicate that its formation is time dependent and suppressible. A second curve, posed at lower temperature, crosses the vertical axis to illustrate the time-dependent formation of insuppressible martensite. The crossing point defines the martensite start temperature for insuppressible martensite formation. Following Kakeshita et al. [64], at $\mathrm{M}_{\mathrm{s}}$ the $-190^{\circ} \mathrm{C}$ in [52]. Ein Beispiel für das mit der Bildung von $\{557\}_{\gamma^{-}}$ Lattenmartensit verbundene Oberflächenrelief ist in Bild $4 \mathrm{zu}$ sehen. $\left\{\begin{array}{lll}1 & 1 & 2\end{array}\right\}_{\gamma}$-Lattenmartensit erscheint als Gruppen von Latten, die in Bändern von entweder $\left\{\begin{array}{lll}1 & 1 & 1\end{array}\right\}_{\gamma^{-}}$-Stapelfehlern oder $\left\{\begin{array}{lll}1 & 1 & 1\end{array}\right\}_{\gamma^{-}}$ Martensitplatten mit hexagonaler Kristallstruktur, sogenanntem epsilon Martensit, eingeschlossen sind [53]. Die Unterstruktur des Martensits von $\alpha$ ' besteht aus Bereichen mit hoher Versetzungsdichte (d. h. verrutschter Martensit). Der Martensit $\left\{\begin{array}{lll}1 & 1 & 2\end{array}\right\}_{\gamma}$ kann sich bei $-269^{\circ} \mathrm{C}$ bilden $[32,54-57]$, und seine Bildung kann die Erzeugung zusätzlicher planarer Defekte $\left\{\begin{array}{lll}1 & 1 & 1\end{array}\right\}_{\gamma}$ in Austenit fördern [53]. Wie im Fall von $\left\{\begin{array}{lll}3 & 10 & 15\end{array}\right\}_{\gamma}$-Dünnblechmartensit nähert sich die spontane Bildung von $\left\{\begin{array}{lll}1 & 1 & 2\end{array}\right\}_{\gamma}$-Martensit kaum dem Abschluss. Dies ist auf die Tatsache zurückzuführen, dass die $\left\{\begin{array}{llll}1 & 1 & 1\end{array}\right\}_{\gamma^{-}}$ Bänder die Austenitkörner während der Umwandlung fortschreitend aufteilen [58].

Die in Tabelle 1 aufgeführten Materialien repräsentieren alle oben genannten Arten von Martensit. Die als Gruppe I klassifizier-

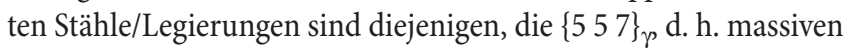
Martensit, entwickeln. Offensichtlich kann die Bildung von massivem Martensit im Gegensatz zu allen anderen Arten von Martensit (Gruppe II) durch schnelles Abkühlen auf siedende Stickstofftemperatur sowie durch Aufheizen unterdrückt werden. Tatsächlich hat sich mit Ausnahme von $\{557\}_{\gamma}$ für alle anderen Martensittypen gezeigt, dass die Umwandlung bei $-269^{\circ} \mathrm{C}$ stattfinden kann $[32,33$, $40,44,45,54-57]$. Interessanterweise wurde zuvor gezeigt, dass beim Härten von reinem Fe die Bildung von massivem Martensit durch Anwendung extrem hoher Abkühlraten unterdrückt werden kann [59-61]. In diesem Fall verwandelt sich der Austenit in ein teilweise verzwillingtes Produkt, identifiziert als $\left\{\begin{array}{llll}2 & 2 & 5\end{array}\right\}_{\gamma^{-}}$ Martensit, bei einer etwa $130{ }^{\circ} \mathrm{C}$ niedrigeren Temperatur, $420{ }^{\circ} \mathrm{C}$ statt $550^{\circ} \mathrm{C}$. Offensichtlich ist die Schlussfolgerung, dass die Bildung von massivem Martensit durch schnelle Abkühlung unterdrückt werden kann, kein Vorrecht der Behandlung unter null Grad Celsius, sondern eher allgemein. Zusätzlich teilen sich der Martensit-\{5 57$\}_{\gamma}$ und der Randbereich des linsenförmigen Martensits die Unterstruktur und die Struktur der Grenzfläche mit dem Mutteraustenit. Daher sind diese Produkte im Wesentlichen identisch. Offensichtlich kann der unterdrückbare Martensit als $\{557\}_{\gamma}$-Lattenmartensit existieren, als der versetzungsreiche Martensit, der auf $\left\{\begin{array}{lll}3 & 10 & 15\end{array}\right\}_{\gamma}$ dünnen Platten wächst, was die Entwicklung zu $\{259\}_{\gamma}$-Linsen fördert, und als der Martensit, der auf verzwillingten $\left\{\begin{array}{lll}2 & 2 & 5\end{array}\right\}_{\gamma}$-Einheiten wächst, was die Verdickung fördert. Huizing und Klostermann waren 1966 die ersten, die diese Rationalisierung vorschlugen [62]. Auf der anderen Seite gibt es den nicht unterdrückbaren Martensit, der allen intern verzwillingten martensitischen Produkten und dem gleitenden Martensit vom Typ $\left\{\begin{array}{lll}1 & 1 & 2\end{array}\right\}_{\gamma}$ entspricht. Es ist wichtig zu bemerken, dass „nicht unterdrückbar" nicht gleichbedeutend mit "zeitunabhängig" oder athermisch ist. Die isotherme Keimbildung von nicht unterdrückbarem Martensit kann auch bei $-269^{\circ} \mathrm{C}$ stattfinden und wurde von anderen ausführlich untersucht $[63,64]$.

In Bild 8 schlagen wir ein schematisches Diagramm vor, um die obige Rationalisierung der Martensitbildung in Stahl zu veranschaulichen. Massiver Martensit wird in Form einer C-Kurve dargestellt, um anzuzeigen, dass seine Bildung zeitabhängig und unterdrückbar ist. Eine zweite Kurve, die bei niedrigerer Temperatur dargestellt wird, kreuzt die vertikale Achse, um die zeitabhängige Bildung von nicht unterdrückbarem Martensit zu veranschaulichen. Der Kreuzungspunkt definiert die Martensit-Starttemperatur 


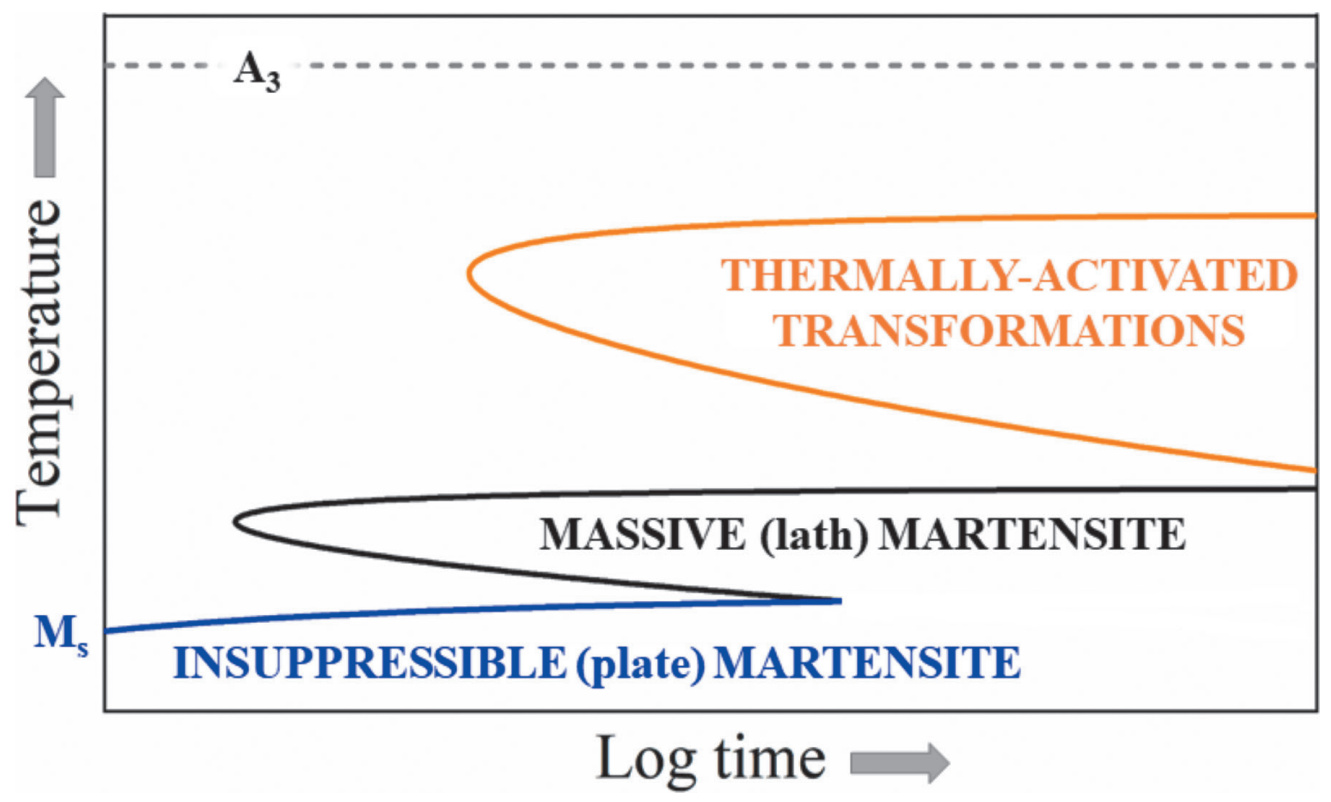

Fig. 8. Schematic TTT diagram illustrating the difference between thermally activated transformations, massive (suppressible) martensite and insuppressible martensite

Bild 8. Schematisches

ZTU-Schaubild zurVeranschaulichung des Unterschieds zwischen thermisch aktivierten Umwandlungen, massivem (unterdrückbarem) Martensit und ununterdrückbarem Martensit

driving force for transformation equals the critical driving force for nucleation and martensite nucleates athermally (i. e. instantaneously). The relative position of the two transformation curves along the temperature axis depends on the chemistry of the steel. For example, it is well known that in $\mathrm{Fe}-\mathrm{C}$ alloys martensite generally shows lath (massive) morphology when the $\mathrm{C}$ content is lower than $0.6 \mathrm{wt} .-\%$, while plate morphology is favored for a higher $\mathrm{C}$ content. This means that at $0.6 \mathrm{wt} .-\% \mathrm{C}$ the relative position of massive and insuppressible martensites with respect to the temperature axis is inverted as compared to the representation in Figure 8 . Hence, plate martensite starts to form at a higher temperature than lath martensite, and the formation of the second is suppressed.

\section{Activation energy for the formation of suppressible martensite}

The rationalization of martensite kinetics in steel as largely thermally activated provides new insight that enables tailoring the thermal treatment of these materials. Thermal activation implies that the transformation can be characterized by an activation energy $\left(\mathrm{E}_{\mathrm{A}}\right)$ in contrast to athermal transformation. The activation energy pertains to the rate-determining mechanism of the transformation and reflects the relation between the temperature and the rate of the transformation, provided that a kinetics model is adopted. In our work, the investigation included several materials where the thermally activated part of the martensitic transformation was attributed to the formation (essentially growth) of suppressible martensite. Moreover, several data sets for the isothermal formation of suppressible martensite can be found in the literature [23]. Consequently, a vast amount of data is available to determine $\mathrm{E}_{\mathrm{A}}$ for this process. für die nicht unterdrückbare Martensitbildung. In Anlehnung an Kakeshita et al. [64] ist bei $\mathrm{M}_{\mathrm{s}}$ die Triebkraft für die Umwandlung gleich der kritischen Triebskraft für die Keimbildung und die Martensit-Keimbildung athermisch (d. h. augenblicklich). Die relative Position der beiden Umwandlungskurven entlang der Temperaturachse hängt von der Chemie des Stahls ab. Es ist zum Beispiel bekannt, dass Martensit in Fe-C-Legierungen im Allgemeinen eine (massive) Lattenmorphologie aufweist, wenn der C-Gehalt unter 0,6 Gew.-\% liegt, während die Plattenmorphologie bei einem höheren C-Gehalt bevorzugt wird. Dies bedeutet, dass bei 0,6 Gew.- $\%$ C die relative Position von massiven und nicht unterdrückbaren Martensiten in Bezug auf die Temperaturachse im Vergleich zur Darstellung in Bild 8 umgekehrt ist. Daher beginnt sich Plattenmartensit bei einer höheren Temperatur als Lattenmartensit zu bilden, und die Bildung des zweiten Martensits wird unterdrückt.

\section{Aktivierungsenergie für die Bildung von unterdrückbarem Martensit}

Die Rationalisierung der Martensit-Kinetik in Stahl, der weitgehend thermisch aktiviert ist, liefert neue Erkenntnisse, die eine maßgeschneiderte thermische Behandlung dieser Materialien ermöglichen. Die thermische Aktivierung impliziert, dass die Umwandlung im Gegensatz zur athermischen Umwandlung durch eine Aktivierungsenergie $\left(\mathrm{E}_{\mathrm{A}}\right)$ charakterisiert werden kann. Die Aktivierungsenergie bezieht sich auf den geschwindigkeitsbestimmenden Mechanismus der Umwandlung und spiegelt die Beziehung zwischen der Temperatur und der Geschwindigkeit der Umwandlung wider, vorausgesetzt, es wird ein Kinetikmodell verwendet. In unserer Arbeit wurden mehrere Materialien untersucht, bei denen der thermisch aktivierte Teil der martensitischen Umwandlung auf die Bildung (im Wesentlichen Wachstum) von unterdrückbarem Martensit zurückzuführen war. Darüber hinaus sind in der Literatur mehrere Datensätze für die isotherme Bildung von unterdrückbarem Martensit zu finden [23]. Folglich steht eine große Menge an Daten zur Verfügung, um $\mathrm{E}_{\mathrm{A}}$ für diesen Prozess zu bestimmen. 
Figure 9 shows that the activation energy for the formation of suppressible martensite lies in the range $0-30 \mathrm{~kJ} / \mathrm{mol}$ and its value increases with the total content of interstitial atoms, $\mathrm{C}$ and $\mathrm{N}$, dissolved in the alloys. The dependence on the total content of interstitials is logarithmic. It was previously demonstrated that the critical cooling rate to suppress the formation of massive martensite in Fe decreases linearly with the logarithm of the fraction of $\mathrm{C}$ atoms present as impurities $[59,60]$. Additionally, small fractions of $\mathrm{C}$ atoms can suppress the formation of massive martensite in Fe-Ni alloys [65-67]. Consequently, the dependence of $E_{A}$ of the total content of interstitials is not surprising and would be consistent with an interaction of dislocations generated in the transformation with interstitially dissolved nitrogen and carbon. Thus, the rate determining step requiring thermal activation is the movement of dislocations associated with martensite formation, either in austenite, in martensite or at the interface. Considering the pinning effect of interstitials on dislocation movement, a higher content of interstitials implies that more thermal activation, i.e. a higher activation energy, is necessary.

\section{Applying the understanding: the impor- tance of the austenitization temperature}

Tool steels are complex systems where austenite and martensite are only two of the main components, along with carbides. Carbides can form during various steps of steel processing: during casting, large $(>5 \mu \mathrm{m})$ carbides of the alloying elements can form; these carbides are thermodynamically stable in ledeburitic grades, for example in AISI D2 (Fe-12Cr-1.5C-1Mo-1V). Moderately large secondary carbides of the alloying elements, say $0.1 \mu \mathrm{m}-5 \mu \mathrm{m}$ in dimension, remain from the austenitization and hardening process. The soft annealing and the austenitization conditions set the population of these carbides. The smallest carbides, generally $<0.1 \mu \mathrm{m}$ in dimension can both be Fe-based carbides and carbides of the alloying elements and they form during
Bild 9 zeigt, dass die Aktivierungsenergie für die Bildung von unterdrückbarem Martensit im Bereich von 0-30 kJ/mol liegt und ihr Wert mit dem Gesamtgehalt an interstitiellen Atomen, $\mathrm{C}$ und $\mathrm{N}$, die in den Legierungen gelöst sind, zunimmt. Die Abhängigkeit vom Gesamtgehalt an interstitiellen Atomen ist logarithmisch. Es wurde bereits gezeigt, dass die kritische Abkühlgeschwindigkeit zur Unterdrückung der Bildung von massivem Martensit in Fe linear mit dem Logarithmus des Anteils der als Verunreinigungen vorhandenen CAtome abnimmt [59, 60]. Zusätzlich können kleine Anteile von CAtomen die Bildung von massivem Martensit in Fe-Ni-Legierungen unterdrücken [65-67]. Folglich ist die Abhängigkeit von $\mathrm{E}_{\mathrm{A}}$ vom Gesamtgehalt an Zwischengitterplätzen nicht überraschend und wäre konsistent mit einer Wechselwirkung von Versetzungen, die bei der Umwandlung erzeugt werden, mit interstitiell gelöstem Stickstoff und Kohlenstoff. Daher ist der ratenbestimmende Schritt, der eine thermische Aktivierung erfordert, die Bewegung von Versetzungen, die mit der Martensitbildung verbunden sind, entweder im Austenit, im Martensit oder an der Grenzfläche. In Anbetracht des Pinning-Effekts von Zwischengitterplätzen auf die Versetzungsbewegung impliziert ein höherer Gehalt an besetzten Zwischengitterplätzen, dass mehr thermische Aktivierung, d. h. eine höhere Aktivierungsenergie, erforderlich ist.

\section{Anwendung des Verständnisses: die Be- deutung der Austenitisierungstemperatur}

Werkzeugstähle sind komplexe Systeme, bei denen Austenit und Martensit zusammen mit Karbiden nur zwei der Hauptbestandteile sind. Karbide können sich während verschiedener Schritte der Stahlverarbeitung bilden: Beim Gießen können sich große (> $5 \mu \mathrm{m}$ ) Karbide der Legierungselemente bilden; diese Karbide sind in ledeburitischen Sorten thermodynamisch stabil, zum Beispiel in AISI D2 (Fe-12Cr-1.5C-1Mo-1V). Mäßig große sekundäre Karbide der Legierungselemente, etwa $0,1 \mu \mathrm{m}-5 \mu \mathrm{m}$, bleiben vom Austenitisierungs- und Aushärtungsprozess übrig. Die Weichglüh- und Austenitisierungsbedingungen bestimmen die Population dieser Karbide. Die kleinsten Karbide, in der Regel kleiner als 0,1 $\mu \mathrm{m}$, können sowohl Karbide auf Fe-Basis als auch

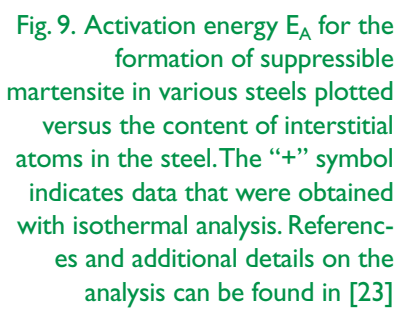

Fig. 9. Activation energy $E_{A}$ for the formation of suppressible martensite in various steels plotted versus the content of interstitial atoms in the steel. The "+" symbol indicates data that were obtained with isothermal analysis. References and additional details on the analysis can be found in [23]

Bild 9. Aktivierungsenergie $E_{A}$ für die Bildung von unterdrückbarem Martensit in verschiedenen Stählen, aufgetragen gegen den Gehalt an Zwischengitteratomen im Stahl. Das "+"-Symbol kennzeichnet Daten, die mit isothermischer Analyse erhalten wurden. Verweise und zusätzliche Details zur Analyse sind in [23] zu finden

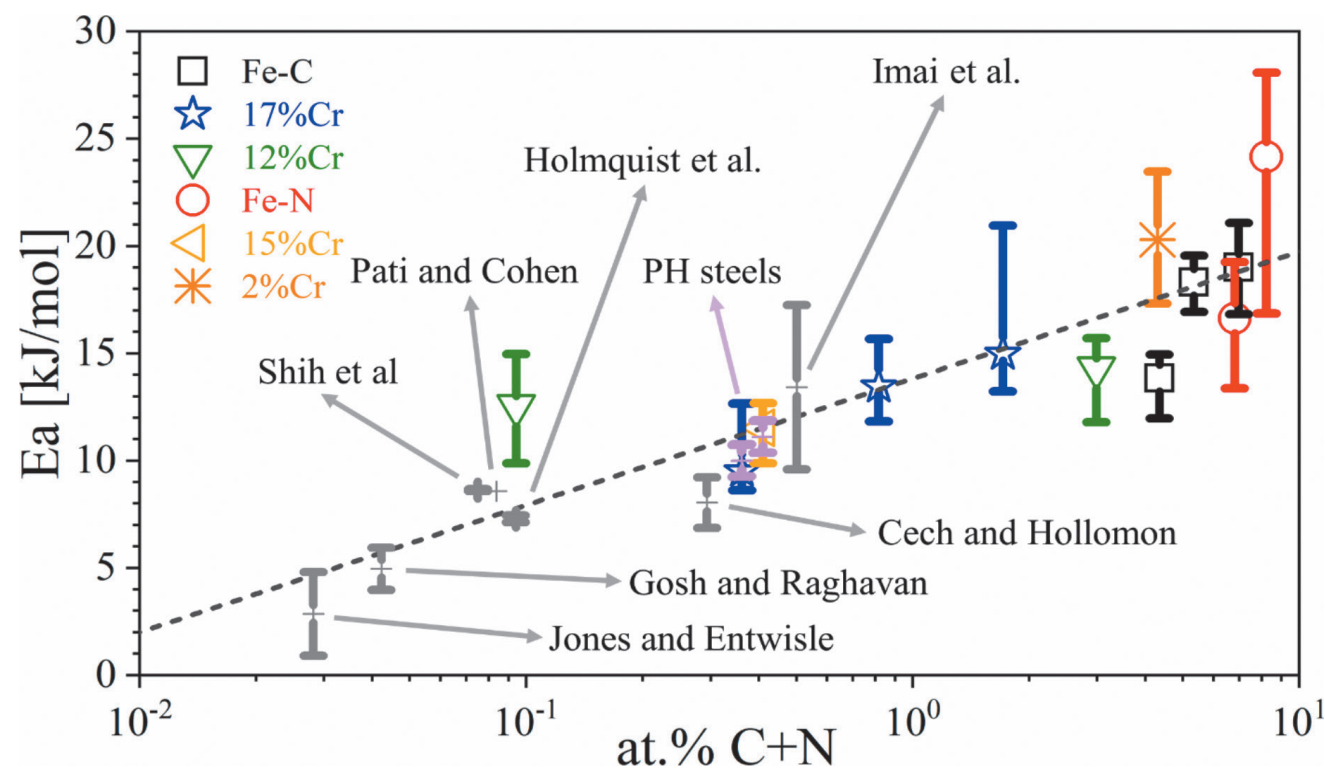


tempering. Tempering is considered the process that has the largest influence on the properties (hence the performance) of tool steels. After the work of Barron [17, 18], extensive activity was dedicated to understand the metallurgy of steel in relation to cryogenic treatments. Several authors reported a positive effect of cryogenic treatment on steel performance, especially wear, and attributed the positive effect to a refined population of carbides. The activities of Collins and co-workers [68] and Das et al. [69] are probably the best known. In both cases, the steel under investigation was AISI D2, which is the material that best responded to cryogenic treatment in Barron et al's work [18]. The material was investigated after tempering and differences among samples were ascribed to the effect of cryogenic treatment on the tempering reactions. Collins et al. considered the population of carbides smaller than $5 \mu \mathrm{m}$ as revealed by optical microscopy (i. e. $>0.5 \mu \mathrm{m}$ ). Their samples were cryogenically treated before tempering and a large number of carbides in the range $0.5-5 \mu \mathrm{m}$ were found; the smallest carbides appeared most abundant in the samples treated at the lowest temperature $\left(-196^{\circ} \mathrm{C}\right)$ for the longest time $(48 \mathrm{~h})$. Wear testing indicated a correlation between the abundance of these "small" carbides and resistance to wear. Das et al. considered carbide size distribution in the ranges $0.1-1 \mu \mathrm{m}, 1-5 \mu \mathrm{m}$ and $>5 \mu \mathrm{m}$ and showed that the samples cryogenically treated to $-196^{\circ} \mathrm{C}$ before tempering contained a higher number of carbides of the smallest size when compared to conventionally treated samples. All carbides were identified as carbides of the alloying elements. It was also reported that the holding time at $-196^{\circ} \mathrm{C}$ influenced the carbide population that was most refined for a $36 \mathrm{~h}$ treatment. Again, data showed a strong correlation between the wear resistance and the number of the carbides of the "smallest" size. It was noted by Farina et al. [70], and reiterated here, that the carbides investigated by Collins et al. and by Das et al. are of dimensions and type that typically form, besides earlier process steps, during austenitization, rather than during tempering. Nevertheless, the relation between an overall reduction of the carbide dimensions and the improved performance of steel could be envisaged in terms of improved mechanical properties, especially increased toughness: large carbides act as weak points in the steel microstructure and could promote premature failure. Consistently, the production of high performance tool steels relies either on processes / chemistry of the metallic alloying elements that yield a fine carbide population or on using nitrogen instead of carbon, as nitrides are typically smaller than carbides.

The importance of the population of carbides $>0.1 \mu \mathrm{m}$ for the performance of steel suggests that the effect of the austenitization temperature on the steel microstructure needs consideration. It is anticipated that the austenitization temperature has an influence on the efficiency of sub-zero Celsius treatment, so these treatments are interdependent. By means of example, a $12 \% \mathrm{Cr}-0.7 \% \mathrm{C}$ steel is considered [71]. This steel is a relatively simple system that may be representative for several steels in tooling and bearing applications. The material was received in soft annealed condition (i. e. $<10 \mu \mathrm{m}$
Karbide der Legierungselemente sein und bilden sich beim Anlassen. Das Anlassen wird als der Prozess betrachtet, der den größten Einfluss auf die Eigenschaften (daher die Leistung) von Werkzeugstählen hat. Nach der Arbeit von Barron $[17,18]$ wurden umfangreiche Aktivitäten unternommen, um die Metallurgie von Stahl im Zusammenhang mit Tieftemperaturbehandlungen zu verstehen. Mehrere Autoren berichteten über eine positive Wirkung der Tieftemperaturbehandlung auf die Stahlleistung, insbesondere auf den Verschleiß, und schrieben die positive Wirkung einer verfeinerten Karbidpopulation zu. Die Aktivitäten von Collins und seinen Mitarbeitenden [68] und Das et al. [69] sind wahrscheinlich die bekanntesten. In beiden Fällen handelte es sich bei dem untersuchten Stahl um AISI D2, der in der Arbeit von Barron et al. [18] das Material ist, das am besten auf die Tieftemperaturbehandlung ansprach. Das Material wurde nach dem Anlassen untersucht, und Unterschiede zwischen den Proben wurden auf die Auswirkung der Tieftemperaturbehandlung auf die Anlass-Reaktionen zurückgeführt. Collins et al. betrachteten die Karbide kleiner als $5 \mu \mathrm{m}$, wie die Lichtmikroskopie ergab (d. h. > 0,5 $\mu \mathrm{m}$ ). Ihre Proben wurden vor dem Anlassen kryogenisch behandelt, und es wurde eine große Anzahl von Karbiden im Bereich von 0,5-5 $\mu \mathrm{m}$ gefunden; die kleinsten Karbide erschienen am häufigsten in den Proben, die bei der niedrigsten Temperatur $\left(-196^{\circ} \mathrm{C}\right)$ am längsten ( $48 \mathrm{~h}$ ) behandelt wurden. Verschleißuntersuchungen zeigten eine Korrelation zwischen der Häufigkeit dieser "kleinen" Karbide und der Verschleißfestigkeit. Das et al. betrachteten die Karbidgrößenverteilung in den Bereichen 0,1-1 $\mu \mathrm{m}, 1-5 \mu \mathrm{m}$ und $>5 \mu \mathrm{m}$ und zeigten, dass die Proben, die vor dem Anlassen kryogenisch auf $-196^{\circ} \mathrm{C}$ behandelt wurden, im Vergleich zu konventionell behandelten Proben eine höhere Anzahl von Karbiden kleinster Größe enthielten. Alle Karbide wurden als Karbide der Legierungselemente identifiziert. Es wurde auch berichtet, dass die Haltezeit bei $-196^{\circ} \mathrm{C}$ die Karbidpopulation beeinflusste, die für eine 36-stündige Behandlung am raffiniertesten war. Auch hier zeigten die Daten eine starke Korrelation zwischen der Verschleißbeständigkeit und der Anzahl der Karbide der "kleinsten" Größe. Farina et al. [70] stellten fest und er wird hier wiederholt, dass sich die von Collins et al. und Das et al. untersuchten Karbide typischerweise beim Austenitisieren und nicht beim Anlassen bilden. Nichtsdestotrotz könnte die Beziehung zwischen einer allgemeinen Verringerung der Karbidabmessungen und der verbesserten Leistung des Stahls im Hinblick auf verbesserte mechanische Eigenschaften, insbesondere erhöhte Zähigkeit, ins Auge gefasst werden: Große Karbide wirken als Schwachstellen im Stahlgefüge und könnten ein vorzeitiges Versagen begünstigen. Konsequenterweise beruht die Herstellung von Hochleistungs-Werkzeugstählen entweder auf Verfahren/Chemie der metallischen Legierungselemente, die eine feine Karbidpopulation ergeben, oder auf der Verwendung von Stickstoff anstelle von Kohlenstoff, da Nitride typischerweise kleiner als Karbide sind.

Die Bedeutung der Karbide $>0,1 \mu \mathrm{m}$ für die Leistungsfähigkeit von Stahl legt nahe, dass der Einfluss der Austenitisierungstemperatur auf die Stahlmikrostruktur berücksichtigt werden muss. Es wird erwartet, dass die Austenitisierungstemperatur einen Einfluss auf die Effizienz der Behandlung bei Temperaturen unter null Grad Celsius hat, sodass diese Behandlungen voneinander abhängig sind. Anhand eines Beispiels wird ein $12 \% \mathrm{Cr}-0,7$ \%C-Stahl betrachtet [71]. Bei diesem Stahl handelt es sich um ein relativ einfaches System, das für mehrere Stähle in Werkzeug- und Lageranwendungen 
large globular carbides in a ferrite matrix) and was austenitized for $1 \mathrm{~h}$ at various temperatures before gas quenching to room temperature. Thereafter, the material was immediately subjected to three types of sub-zero Celsius treatment: cold treatment in dry ice (i. e. $-78^{\circ} \mathrm{C}$ ) for $24 \mathrm{~h}$; cryogenic treatment consisting of immersion in boiling nitrogen (i.e. $-196^{\circ} \mathrm{C}$ ) for 5 minutes, followed by up-quenching in water (cryo + up-quenching); cryogenic treatment consisting of immersion in boiling nitrogen 5 minutes followed by storage in dry ice for $24 \mathrm{~h}$ (cryo + cold treatment). The microstructure of the material in the condition hardened to room temperature was investigated with optical microscopy.

Figure 10 shows that for the lowest applied austenitization temperature, i. e. $1010^{\circ} \mathrm{C}$, the microstructure of the steel consists of a large number of carbides that can exceed $1 \mu \mathrm{m}$ dispersed in a matrix of fine massive lath martensite. With an increase in austenitization temperature, the total number and the average size of the carbides decreases, while the martensite morphology changes from massive lath to plate martensite. Moreover, the micrograph for the material treated at $1130{ }^{\circ} \mathrm{C}$ shows the presence of retained austenite, which becomes the majority phase at the highest temperature applied, i. e. $1190^{\circ} \mathrm{C}$. Simultaneously, the prior austenite grain size increases, leading to an overall coarsening of the microstructure. All these effects follow from enhanced solubility of the alloying elements in the austenite with increasing temperature. Firstly, the higher solubility of $\mathrm{C}$ and $\mathrm{Cr}$ in austenite promotes dissolution of the carbides from the soft-annealed condition. Secondly, the dissolution of carbides removes the obstacles for grain growth. Lastly, $\mathrm{C}$ and $\mathrm{Cr}$ in solid solution lower $\mathrm{M}_{\mathrm{s}}$, thus increasing the fraction of retained austenite and promoting a transition of the martensite morphology from massive into plate. repräsentativ sein kann. Das Material wurde in weichgeglühtem Zustand (d. h. große kugelförmige Karbide, $<10 \mu \mathrm{m}$, in einer Ferritmatrix) erhalten und vor der Gasabschreckung auf Raumtemperatur $1 \mathrm{~h}$ lang bei verschiedenen Temperaturen austenitisiert. Danach wurde das Material sofort drei Arten der Behandlungsvarianten bei Temperaturen unter null Grad Celsius unterzogen: Kältebehandlung in Trockeneis (d. h. $-78^{\circ} \mathrm{C}$ ) für $24 \mathrm{~h}$; kryogene Behandlung, bestehend aus Eintauchen in siedenden Stickstoff (d.h. $-196^{\circ} \mathrm{C}$ ) für 5 Minuten, gefolgt von einer Aufschreckung in Wasser (Kryo + Aufschreckung); kryogene Behandlung, bestehend aus Eintauchen in siedenden Stickstoff für 5 Minuten, gefolgt von einer Lagerung in Trockeneis für $24 \mathrm{~h}$ (Kryo + Kältebehandlung). Die Mikrostruktur des Materials im auf Raumtemperatur gehärteten Zustand wurde mit Lichtmikroskopie untersucht.

Bild 10 zeigt, dass für die niedrigste angewandte Austenitisierungstemperatur, d. h. $1010^{\circ} \mathrm{C}$, die Mikrostruktur des Stahls aus einer großen Anzahl von Karbiden besteht, die $1 \mu \mathrm{m}$ überschreiten können und in einer Matrix aus feinem, massivem Lattenmartensit dispergiert sind. Mit einer Erhöhung der Austenitisierungstemperatur nimmt die Gesamtzahl und die durchschnittliche Größe der Karbide ab, während sich die Martensitmorphologie von massivem Lattenmartensit zu Plattenmartensit ändert. Außerdem zeigt das Schliffbild für das bei $1130^{\circ} \mathrm{C}$ behandelte Material das Vorhandensein von Restaustenit, der bei der höchsten angewandten Temperatur, d. h. bei $1190^{\circ} \mathrm{C}$, zur Majoritätsphase wird. Gleichzeitig nimmt die (vorherige) Austenitkorngröße zu, was zu einer allgemeinen Vergröberung des Gefüges führt. All diese Effekte resultieren aus einer verbesserten Löslichkeit der Legierungselemente im Austenit mit zunehmender Temperatur. Erstens fördert die höhere Löslichkeit von $\mathrm{C}$ und $\mathrm{Cr}$ im Austenit die Auflösung der Karbide aus dem weichgeglühten Zustand. Zweitens werden durch die Auflösung von Karbiden die Hindernisse für das Kornwachstum beseitigt. Schließlich senken $C$ und $\mathrm{Cr}$ im Mischkristall $\mathrm{M}_{\mathrm{s}}$, wodurch der Anteil an Restaustenit erhöht und ein Übergang der Martensitmorphologie vom Massiv in die Platte gefördert wird.

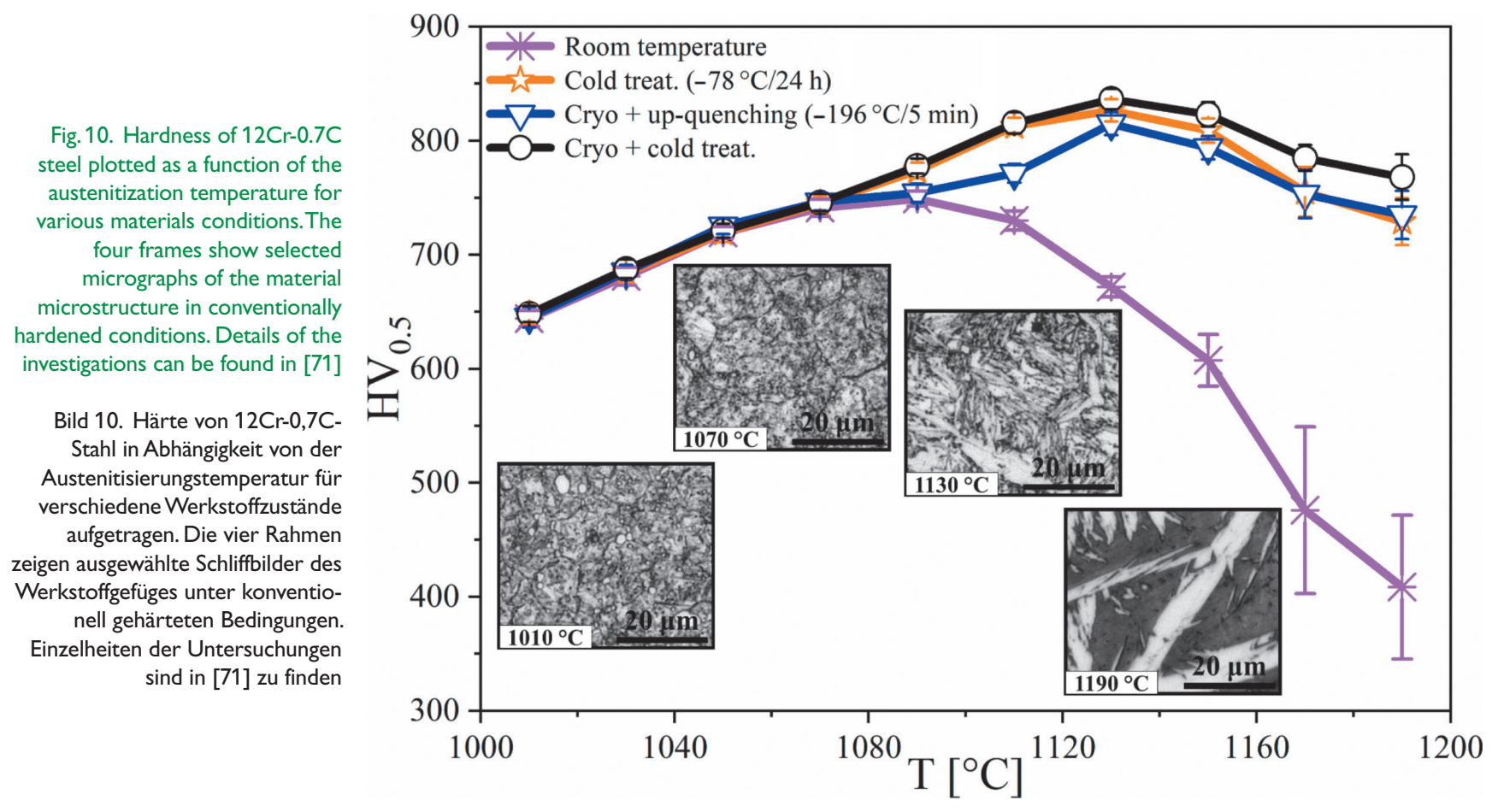


Figure 10 also reports the hardness. Peak hardness for the material quenched to room temperature is observed at $1090^{\circ} \mathrm{C}$ and is approximately $750 \mathrm{HV}$. Sub-zero Celsius treatment shifts the peak hardness to $1130{ }^{\circ} \mathrm{C}$ and to values reaching $840 \mathrm{HV}$. This effect is analogous to the effect of cryogenic treatment on $\mathrm{C}$ steel presented in Figure 2. Nevertheless, in the present case, the effectiveness of the three sub-zero Celsius treatments in reducing the fraction of retained austenite (and increasing hardness) varies with the austenitization temperature. At $1090^{\circ} \mathrm{C}$, cold treatment is effective, while immersion in boiling nitrogen followed by up-quenching in water is not. This behavior reflects the presence of massive martensite, for which (additional) martensite formation is fully suppressible. Insuppressible martensite forms first for $\mathrm{T} \geq 1110^{\circ} \mathrm{C}$, as reflected by the hardening effect of the cryo + up-quenching treatment, for which the hardness increase is attributed to insuppressible martensite formation during cooling. This behavior reflects the change in martensite morphology from massive to plate. Interestingly, in the temperature interval of practical interest, say up to the peak hardness position for sub-zero Celsius treated materials, cryo + up-quenching is never as effective as cold treatment for this material. As shown in the previous paragraphs, controlled slow heating conditions promote (lath) martensite formation, rather than reaching a low temperature. This concept is also expressed by the cryo + cold treatment condition in Figure 10, where the potential additional effect of cryogenic treatment vs. cold treatment is revealed by comparison with the cold treatment line. Only for $\mathrm{T} \geq 1130^{\circ} \mathrm{C}$ (plate martensite) a properly performed cryogenic treatment would be more effective than a cold treatment in reducing the fraction of retained austenite.

Before concluding, it is worth commenting on coarsening of the microstructure. In the present example, an increase of the austenitization temperature to $1130{ }^{\circ} \mathrm{C}$, corresponding the position for peak hardness in sub-zero Celsius treated samples, and the minimum temperature for which cryogenic treatment is worth considering when compared to cold treatment, yields an unwanted coarsening effect on the microstructure. This observation suggests that the austenitization temperature for this steel should never reach $1130{ }^{\circ} \mathrm{C}$ and that it is unlikely that a properly designed cryogenic treatment would significantly over-perform a cold treatment. A completely different situation would apply in the case of ledeburitic grades, such as AISI D2, where large insoluble carbides prevent coarsening of the microstructure. For these steels a high austenitization temperature followed by a cryogenic treatment is most likely to yield steel products with (potentially) superior mechanical properties when compared to other types of treatments.

In conclusion, the example presented shows that the choice of a proper combination of austenitization temperature and sub-zero Celsius treatment can simultaneously yield a harder material with a refined carbide population. Nevertheless, the procedure has the
Bild 10 zeigt auch die Härte. Die Spitzenhärte für das auf Raumtemperatur abgeschreckte Material wird bei $1090^{\circ} \mathrm{C}$ beobachtet und beträgt etwa $750 \mathrm{HV}$. Bei einer Behandlung unter null Grad Celsius verschiebt sich die Spitzenhärte auf $1130{ }^{\circ} \mathrm{C}$ und auf Werte, die $840 \mathrm{HV}$ erreichen. Dieser Effekt ist analog zu dem in Bild 2 dargestellten Effekt der Tieftemperaturbehandlung auf C-Stahl. Dennoch variiert im vorliegenden Fall die Wirksamkeit der drei Unter-Null-Celsius-Behandlungen zur Verringerung des Anteils an Restaustenit (und zur Erhöhung der Härte) mit der Austenitisierungstemperatur. Bei $1090^{\circ} \mathrm{C}$ ist die Kältebehandlung (Cold treatment) wirksam, während das Eintauchen in siedenden Stickstoff mit anschließendem Aufschrecken in Wasser nicht wirksam ist. Dieses Verhalten spiegelt das Vorhandensein von massivem Martensit wider, bei dem die (zusätzliche) Martensitbildung vollständig unterdrückt werden kann. Bei $\mathrm{T} \geq 1110^{\circ} \mathrm{C}$ bildet sich zuerst nicht unterdrückbarer Martensit, was sich in der Härtungswirkung der Kryo + Aufschreckbehandlung (Cryo+upquenching) widerspiegelt, bei der der Härteanstieg auf die nicht unterdrückbare Martensitbildung während der Abkühlung zurückgeführt wird. Dieses Verhalten spiegelt die Änderung der Martensitmorphologie von massiv zu plättchenförmig wider. Interessanterweise ist in dem Temperaturintervall von praktischem Interesse, etwa bis zur Position der Spitzenhärte bei Werkstoffen, die bei Temperaturen unter null Grad Celsius behandelt wurden, die Kryo + Aufschreckbehandlung nie so effektiv wie die Kältebehandlung für diesen Werkstoff. Wie in den vorherigen Abschnitten gezeigt wurde, fördern kontrollierte langsame Erwärmungsbedingungen die (Latten-)Martensitbildung, anstatt eine niedrige Temperatur zu erreichen. Dieses Konzept kommt auch in der Kryo + Kaltbehandlungsbedingung (Cryo + cold treatm.) in Bild 10 zum Ausdruck, wo der potenzielle zusätzliche Effekt der kryogenen Behandlung gegenüber der Kältebehandlung durch den Vergleich mit der Kältebehandlungslinie deutlich wird. Nur für $\mathrm{T} \geq 1130{ }^{\circ} \mathrm{C}$ (Plattenmartensit) wäre eine ordnungsgemäß durchgeführte Tieftemperaturbehandlung wirksamer als eine Kältebehandlung, um den Anteil des Restaustenits zu reduzieren.

Bevor wir zum Schluss kommen, lohnt es sich, auf die Vergröberung des Gefüges einzugehen. Im vorliegenden Beispiel führt eine Erhöhung der Austenitisierungstemperatur auf $1130{ }^{\circ} \mathrm{C}$, die der Position für die Spitzenhärte bei Proben mit einer Temperatur unter null Grad Celsius und der Mindesttemperatur entspricht, für die eine Tieftemperaturbehandlung im Vergleich zur Kältebehandlung in Betracht gezogen werden sollte, zu einer unerwünschten Vergröberung des Gefüges. Diese Beobachtung deutet darauf hin, dass die Austenitisierungstemperatur für diesen Stahl niemals $1130{ }^{\circ} \mathrm{C}$ erreichen sollte und dass es unwahrscheinlich ist, dass eine richtig ausgelegte Tieftemperaturbehandlung eine Kaltbehandlung wesentlich übertreffen würde. Eine völlig andere Situation würde bei ledeburitischen Sorten wie AISI D2 eintreten, wo große unlösliche Karbide eine Vergröberung des Gefüges verhindern. Bei diesen Stählen führt eine hohe Austenitisierungstemperatur, gefolgt von einer Tieftemperaturbehandlung, höchstwahrscheinlich zu Stahlprodukten mit (potenziell) überlegenen mechanischen Eigenschaften im Vergleich zu anderen Arten von Behandlungen.

Abschließend zeigt das vorgestellte Beispiel, dass die Wahl einer geeigneten Kombination aus Austenitisierungstemperatur und einer Behandlung unter null Grad Celsius gleichzeitig ein härteres Material mit einer veredelten Karbidpopulation ergeben 
disadvantage of a significant coarsening of the microstructure. In this respect, ledeburitic steels present safer conditions. The likelihood that cryogenic treatment over-performs cold treatment in minimizing the content of retained austenite increases with higher austenitization temperature and it can be evaluated by the material's microstructure and the martensite morphology.

\section{Conclusions}

Sub-zero Celsius treatments were conceived for the first time about a century ago as a means to reduce the fraction of retained austenite in medium-high carbon steels. Considerable progress was made in the following decades, but practical application and metallurgical understanding of the phenomena involved have not always gone along. Nowadays, it is comprehended that the formation of isothermal (i. e. thermally activated) martensite has always played a fundamental role in the success of sub-zero Celsius treatments.

The present review shows that thermally activated martensite formation in steel during sub-zero Celsius treatment is the rule rather than the exception. This implies that martensite can form on cooling, isothermally as well as on heating. Some martensite can be suppressed, which is clearly in contradiction with the general idea about martensite, while other martensite cannot be suppressed. In the large majority of steels, the suppressibility of martensite depends on its internal structure. If twinning is operable, like in (thin) plate martensite, martensite formation is insuppressible; for an internal structure consisting of dislocations, i. e. lath (massive) martensite, the formation of the martensitic product is suppressible. The activation energy associated with thermally activated (suppressible) martensite formation depends on the interstitial content in austenite, because they are effective barriers that hamper dislocation movement.

This review demonstrates that the type of martensite, plate vs. massive lath, determines the temperature interval where the martensitic transformation proceeds. Massive lath (suppressible) martensite forms effectively at temperatures typical of cold treatments, i. e. around $-80^{\circ} \mathrm{C}$, while its formation is largely inhibited at cryogenic temperatures. Plate martensite can form in the whole sub-zero Celsius temperature range and shows time dependent transformation kinetics at cryogenic temperatures. Consistently, cold treatments are prescribed for the conversion of austenite into martensite in steels characterized by lath martensite (as particular PH stainless steels), while medium-high carbon steels, wherein plate martensite forms at sub-zero Celsius temperatures, can show a significant improvement in performance when subjected to cryogenic treatments.

In addition to the general conclusion above, a practical example on a martensitic stainless steel with $12 \% \mathrm{Cr}$ and $0.7 \% \mathrm{C}$ shows that the efficiency of a pre-defined sub-zero Celsius treatment depends strongly on the austenitization conditions. For higher austenitiza- kann. Dennoch hat das Verfahren den Nachteil einer deutlichen Vergröberung des Gefüges. In dieser Hinsicht stellen ledeburitische Stähle sicherere Bedingungen dar. Die Wahrscheinlichkeit, dass die Tieftemperaturbehandlung die Kaltbehandlung bei der Minimierung des Restaustenitgehalts übertrifft, steigt mit höherer Austenitisierungstemperatur und kann anhand der Mikrostruktur des Werkstoffs und der Martensitmorphologie beurteilt werden.

\section{Schlussfolgerungen}

Behandlungen unter null Grad Celsius wurden zum ersten Mal vor etwa einem Jahrhundert konzipiert, um den Anteil an Restaustenit in Stählen mit mittlerem und hohem Kohlenstoffgehalt zu reduzieren. In den folgenden Jahrzehnten wurden beträchtliche Fortschritte erzielt, aber die praktische Anwendung und das metallurgische Verständnis der beteiligten Phänomene sind nicht immer mitgegangen. Heutzutage ist verstanden, dass die Bildung von isothermem (d. h. thermisch aktiviertem) Martensit immer eine grundlegende Rolle für den Erfolg von Behandlungen unter null Grad Celsius gespielt hat.

Die vorliegende Übersicht zeigt, dass die thermisch aktivierte Martensitbildung in Stahl während einer Behandlung unter null Grad Celsius eher die Regel als die Ausnahme ist. Dies impliziert, dass sich Martensit sowohl beim Abkühlen, isotherm als auch beim Erhitzen bilden kann. Ein Teil des Martensits kann unterdrückt werden, was eindeutig im Widerspruch zu der allgemeinen Vorstellung über Martensit steht, während anderer Martensit nicht unterdrückt werden kann. In der großen Mehrheit der Stähle hängt die Unterdrückbarkeit von Martensit von seiner inneren Struktur ab. Wenn Zwillingsbildung möglich ist, wie z. B. bei (dünnem) Plattenmartensit, ist die Martensitbildung nicht unterdrückbar; bei einer inneren Struktur, die aus Versetzungen besteht, d. h. (massiver) Lattenmartensit, ist die Bildung des martensitischen Produkts unterdrückbar. Die Aktivierungsenergie, die mit der thermisch aktivierten (unterdrückbaren) Martensitbildung verbunden ist, hängt vom interstitiellen Gehalt im Austenit ab, da sie wirksame Barrieren sind, die die Versetzungsbewegung behindern.

Diese Übersicht zeigt, dass die Art des Martensits, Platte vs. massive Latte, das Temperaturintervall bestimmt, in dem die martensitische Umwandlung fortschreitet. Bei Temperaturen, die für Kältebehandlungen typisch sind, d. h. bei etwa $-80^{\circ} \mathrm{C}$, bildet sich (unterdrückbarer) massive Lattenmartensit effektiv, während seine Bildung bei kryogenen Temperaturen weitgehend gehemmt wird. Plattenmartensit kann sich im gesamten Temperaturbereich unter null Grad Celsius bilden und zeigt bei kryogenen Temperaturen eine zeitabhängige Umwandlungskinetik. Für die Umwandlung von Austenit in Martensit in Stählen, die sich durch Lattenmartensit auszeichnen (wie z. B. bestimmte PH-Edelstähle), werden durchweg Kaltbehandlungen vorgeschrieben, während Stähle mit mittlerem Kohlenstoffgehalt, bei denen sich bei Temperaturen unter null Grad Celsius Plattenmartensit bildet, eine erhebliche Leistungsverbesserung zeigen können, wenn sie kryogenen Behandlungen unterzogen werden.

Zusätzlich zu der obigen allgemeinen Schlussfolgerung zeigt ein praktisches Beispiel an einem martensitischen rostfreien Stahl mit $12 \%$ Cr und 0,7\% C, dass die Effizienz einer vordefinierten Behandlung unter null Grad Celsius stark von den Austenitisie- 
tion temperatures, cryogenic treatments acquire additional relevance over cold treatments, along with a change in the carbon content in austenite and the change in morphology of martensite.

\section{References}

1. Baldissera, P.; Delprete, C.: Current and Potential Applications of Cryogenic Treated Polymers. Polymers at Cryogenic Temperatures. S. Kalia, S. Y. Fu (eds.), Springer-Verlag, Berlin, 2013, pp. 275-286, DOI:10.1007/978-3-642-35335-2_12

2. Razavykia, A.; Delprete, C.; Baldissera, P.: Correlation between Microstructural Alteration, Mechanical Properties and Manufacturability after Cryogenic Treatment: A Review. Materials 12 (2019) 20,3302, DOI:10.3390/ma12203302, open access

3. Greer, L.; Sun., Y. H.: Stored energy in metallic glasses due to strains within the elastic limit. Phil. Mag. 96 (2016) 16, pp. 1643-1663, DOI:10.1080/14786435.2016.117723, open access

4. Vander Voort, G.F. (ed.): Atlas of Time-Temperature Diagrams for Irons and Steels. ASM International, Materials Park, OH, USA, 1991. - ISBN: 0-87170-415-3

5. Koistinen, D. P.; Marburger, R. E.: A general equation prescribing the extent of the austenite-martensite transformation in pure Iron-Carbon alloys and plain Carbon steels. Acta Metall 7 (1959) 1, pp. 59-60, DOI:10.1016/0001-6160(59)90170-1

6. Van Bohemen, S. M. C.; Sietsma, J.: Effect of Composition on Kinetics of Athermal Martensite Formation in Plain Carbon Steels. Mater. Sci. Technol. 25 (2009) 8 pp. 1009-1012, DOI:10.1179/174328408X365838

7. Mathews, J. A.: Austenite and Austenitic Steels. Trans. AIME 71 (1925), pp. 568-596

8. Gulyaev, A. P.: Treatment of steel with cold. Vestn. Inzh. Tekh. 4-5 (1946), pp. 140-147

9. Gordon, P.; Cohen, M.: The transformation of retained austenite in high speed steel at subatmospheric temperatures. Trans. ASM 30 (1942), pp. 569-588

10. Cohen, M.: Retained austenite (Prof. Campbell Memorial lecture). Trans. ASM 41 (1949), pp. 35-94

11. Villa, M.; Hansen, M. F.; Somers, M. A. J.: Martensite Formation in Fe-C Alloys at Cryogenic Temperatures. Scr. Mater. 141 (2017), pp. 129-132, DOI:10.1016/ j.scriptamat.2017.08.005

12. Van Bohemen, S. M. C.: Bainite and Martensite Start Temperature Calculated with Exponential Carbon Dependence. Mater. Sci. Technol. 28 (2012) 4, pp. 487-495, DOI:10.1179/1743284711Y.0000000097

13. Slunder, C. J.; Hoenie, A. F.; Hall, A. M.: Thermal and Mechanical Treatment for Precipitation-Hardening Stainless Steel. NASA, Washington, D. C., USA, 1967

14. Kurdjumov, G. V.; Maksimova, O.P.: O kinetike prevrashcheniya austenitica v martensit pri nizikh temperaturah. Dokl Akad Nauk SSSR 61 (1948) 1, pp. 83-86

15. Gulyaev, P. A.; Makarov, V.M.: Martensitic Transformation, Mechanical Properties, and Structure of Austenitic-Martensitic Stainless Steels. Metal Sci. and Heat Treat. of Metals 2 (1960) 8, pp. 419-423, DOI:10.1007/bf00656470

16. Villa, M.; Hansen, M. F; Somers, M. A. J.: The Sub-Zero Celsius Treatment of Precipitation Hardenable Semi-Austenitic Stainless Steel. Proc. of the 28th ASM Heat Treating Society Conference, 20.-22.10.15, Detroit, USA, ASM Int., Curran Associates, Red Hook, NY, 2016, pp. 431-435. - ISBN: 9781510815100

17. Barron, R. F.: Effect of cryogenic treatment on lathe tool wear. Prog. Refrig. Sci. Technolog. 1 (1973), pp. 529-533

18. Barron, R. F.: Cryogenic treatment of metals to improve wear resistance. Cryogenics 22 (1982) 8, pp. 409-413, DOI:10.1016/0011-2275(82)90085-6

19. Carlson, E. A.: Cold Treating and cryogenic treatment of steel. ASM Handbook 4 R. T. Kiepura, H. F. Lampman, N. D. Wheaton (eds.), ASM Int. Metals Park, OH, USA, 1991, pp. 203-206. - ISBN: 0-87170-379-3

20. Collins, D. N.: Deep cryogenic treatment of tool steels: a review. Heat treat. of metals 2 (1996), pp. 40-42, DOI:10.1179/174951508X446367

21. Zhao, J. C.; Notis, M. R.: Continuous cooling transformation kinetics versus isothermal transformation kinetics of steels: a phenomenological rationalization of experimental observations. Mater. Sci. Eng. R. 15 (1995) 4-5, pp. 135-207, DOI:10.1016/0927-796x(95)00183-2

22. Mittemeijer, E. J.: Analysis of the kinetics of phase transformation. J Mater Sci 27 (1992) 15, pp. 3977-3987, DOI:10.1007/bf01105093

23. Villa, M.; Somers, M. A. J.: Activation energy of time-dependent martensite formation in steel. Proc. ICOMAT 2017, 09.-14.07.17, Chicago, IL, USA, A. Stebner G. B. Olson (eds), The Minerals, Metals \& Materials Society, Springer, Cham, 2018, pp. 13-19. - ISBN: 9783319769677 rungsbedingungen abhängt. Bei höheren Austenitisierungstemperaturen gewinnen Tieftemperaturbehandlungen gegenüber Kältebehandlungen zusätzliche Bedeutung, die mit einer Änderung des Kohlenstoffgehalts im Austenit und einer Änderung der Morphologie des Martensits zusammenhangt.

24. Villa, M.; Christiansen, T. L.; Hansen, M. F.; Somers, M. A. J.: Martensitbildung in Fe-basierten Legierungen während der Erwärmung von Stickstoff-Siedetemperatur. HTM J. Heat Treatm. Mat. 71 (2016) 1, pp. 1-8, DOI:10.3139/ 105.110276

25. Villa, M.; Christiansen, T. L.; Hansen, M. F.; Somers, M. A. J.: Investigation of Martensite Formation in Fe Based Alloys During Heating From Boiling Nitrogen Temperature. Metall. Ital. 11 (2015) 12, pp. 39-46

26. Villa, M.; Somers, M. A. J.: Thermally Activated Martensite Formation in Ferrous Alloys. Scr. Mater. 142 (2017), pp. 46-49, DOI:10.1016/j.scriptamat.2017.08.024

27. McDougall, P. G.; Wayman, C. M.: The crystallography and morphology of ferrous martensites. Martensite - A tribute to Morris Cohen. G. B. Olson, W. S. Owen (eds.), ASM International, Cleveland, OH, USA, 1992, pp. 59-96

28. Maki, T.: Morphology and Substructure of Martensite in Steels. Phase Transformations in Steels, Vol. 2, E. Pereloma, D. V. Edmonds (eds.), Woodhead Publishing Limited, Cambridge, UK, 2012, pp. 34-58

29. Kelly, P. M.; Nutting, J.: Morphology of Martensite. J. Iron and Steel Inst. 198 (1961), pp. 199-211

30. Krauss, G.; Marder, A.R.: The Morphology of Martensite in Iron Alloys. Metal. Trans. A 2 (1971) 9, pp. 2343-2357, DOI:10.1007/bf02814873

31. Miyamoto, G.; Shibata, A.; Maki, T.; Furuhara, T.: Precise measurement of strain accommodation in austenite matrix surrounding martensite in ferrous alloys by electron. Acta Mater. 57 (2009) 4, pp. 1120-1131, DOI:10.1016/j.actamat.2008.10.050

32. Kulin, S.; Cohen, M.: On the martensitic transformation at temperatures approaching absolute zero. JOM 2 (1950) 9, pp. 1139-1143, DOI:10.1007/bf03399112

33. Xie, Z. L.; Hanninen, H.; Pietikainen, J.: Substructure of thin-plate martensite formed under applied plane stress at 4 K. Scripta Metall. Mater. 28 (1993) 11, pp. 1423-1428, DOI:10.1016/0956-716x(93)90493-c

34. Sadovskii, V.D.; Romashev, L. N.: Growth of martensite crystals formed under the effect of a pulsed magnetic field. Soviet Physics - Doklady 23 (1978) 1, pp. 77-79

35. Shibata, A.; Murakami, T.; Morito, S.; T. Furuhara, T.; Maki, T.: The origin of midrib in lenticular martensite. Mater. Trans. 49 (2008) 6, pp. 1242-1248, DOI:10.2320/matertrans.mra2007296

36. Lee, H. J.; Yen, H. W.; Chang, H. T.; Yang, J. R.: Substructures of martensite in Fe1C-17Cr stainless steel. Scripta Mater. 62 (2010) 9, pp. 670-673, DOI:10.1016/ j.scriptamat.2010.01.022

37. Kakeshita, T.; Shimizu, K.; Maki, T.; Tamura, I.: Growth behaviour of lenticular and thin plate martensites in ferrous-alloys and steels. Scripta Metal. 14 (1980) 10, pp. 1067-1070, DOI:10.1016/0036-9748(80)90207-0

38. Shibata, A.; Furuhara, T.; Maki, T.: Interphase boundary structure and accommodation mechanism of lenticular martensite in Fe-Ni alloys. Acta Mater. 58 (2010) 9 , pp. 3477-3492, DOI:10.1016/j.actamat.2010.02.022

39. Crangle, J.; Goodman, G. M.: The Magnetization of Pure Iron and Nickel. Proc. Rol. Soc. Lond. A 321 (1971) 1547, pp. 477-491, DOI:10.1098/rspa.1971.0044

40. Reed, R. P.: The plate-like martensite transformation in Fe-Ni alloys. Acta Metal. 15 (1967) 8, pp. 1287-1296, DOI:10.1016/0001-6160(67)90004-1

41. Yang, D.-Z.; Sandvik, B. P. J.; Wayman, C. M.: On the substructure of athermal and isothermal martensites formed in an Fe-21Ni-4Mn alloy. Metall. Trans. A 15 (1984) 8, pp. 1555-1562, DOI:10.1007/bf02657794

42. Jana, S.; Wayman, C. M.: The Morphology and Substructure of [225]F Martensite in an Fe-Mn-Cr-C Alloy. Metall. Trans. A 1 (1970) 10, pp. 2825-2832

43. Shimizu, K.; Oka, M.; Wayman, C. M.: The Association of Martensite Platelets with Austenite Stacking Faults in an Fe-8Cr-1C Alloy. Acta Metall. 18 (1970) 9, pp. 1005-1011, DOI:10.1016/0001-6160(70)90056-8

44. Kakehita, T.; Saburi, T.; Kindo, K.; Endo, S.: Martensitic transformations in some ferrous and non-ferrous alloys under magnetic field and hydrostatic pressure. Phase Trans. 70 (1999) 2, pp. 65-113, DOI:10.1080/01411599908240678

45. Schastlivtsev, V. M.; Kaletina, Y. V.; Fokina, E. A.; Korolev, A. V.; Marchenkov, V. V.: Effect of a dc magnetic field on the isothermal martensitic transformation in the Fe-24Ni-4Mn alloy. Phys. Metal. Metall. 91 (2001) 2, pp. 165-172 
46. Ghosh, G.; Raghavan, $V .:$ The dimension of isothermally formed martensitic plates in an Fe-Ni-Mn alloy. Mater. Sci. Eng. 79 (1986) 2, pp. 223-231, DOI:10.1016/00255416(86)90407-6

47. Kelly, P. M.; Nutting, J.: The Martensite Transformation in Carbon Steels. Proc. R Soc. London A 259 (1960) 1296, pp. 45-58, DOI:10.1098/rspa.1960.0210

48. Speich, G. R.; Swann, P. R.: Yield Strength and Transformation Substructure of Quenched Iron-Nickel Alloys. J. Iron Steel Inst. 203 (1965), pp. 480-485

49. Marder, J. M.; Marder, A. R.: Morphology of Iron-Nickel Massive Martensite. ASM Trans. 62 (1969) 1, pp. 1-10

50. Morito, S.; Huang, X.; Furuhara, T.; Maki, T.; Hansen, N.: The Morphology and Crystallography of Lath Martensite in Alloy Steels. Acta Mater. 54 (2006) 19, pp. 5323-5331, DOI:10.1016/j.actamat.2006.07.009

51. Moritami, T.; Miyajima, N.; Furuhara, T.; Maki, T.: Comparison of interphase boundary structure between bainite and martensite in steel. Scripta Mater. 47 (2002) 3, pp. 193-199

52. San Martin, D.; van Dijk, N. H.; Jimenez-Melero, E.; Kampert, E.; Zeitier, U.; van der Zwaag, S.: Real-Time Martensitic Transformation Kinetics in Maraging Steel under High Magnetic Fields. Mater. Sci. Eng. A 527 (2010) 20, pp. 5241-5245

53. Breedis, J. F.; Kaufman, L.: The Formation of Hcp and Bcc Phases in Austenitic Iron Alloys. Metall. Trans. A 2 (1971) 9, pp. 2359-2371

54. Kurita, Y.; Emura, S.; Fujita, K.; Nagai, K.; Ishiwaka, K.; Shibata, K.: Effects of magnetic field on martensitic transformation and serration of austenitic Fe-Ni and Fe-Ni-Cr steels at $4 \mathrm{~K}$. Fusion Eng. Design 20 (1993), pp. 445-450, DOI:10.1016/0920-3796(93)90077-U

55. Lee, J.; Fukuda, T.; Kakeshita, T.; Kindo, K.: Effects of Magnetic Field and Deformation on Isothermal Martensitic transformation in SUS304 and SUS304L steels. Mater. Trans. 48 (2007) 11, pp. 2833-2839, DOI:10.2320/matertrans.MI200715

56. Larbalestier, D. C.; King, H. W.: Austenitic Stainless Steels at Cryogenic Temperatures. I. Structural Stability and Magnetic Properties. Cryogenics 13 (1973) 3, pp. 160-168, DOI:10.1016/0011-2275(73)90285-3

57. Reed, Mikesell, R. P.: The stability of austenitic stainless steels at low temperatures as determined by magnetic measurements. Advances in Cryogenic Engineering 4. K. D. Timmerhaus (ed.), Plenum Pres. Inc., New York, USA, 1960, p. 84

58. Miyagi, M.; Wayman, C. M.: Martensitic Transformations in Iron-Iridium Alloys. Trans. AIME 236 (1966) 5, pp. 806-811

59. Mirzayev, D. A.; Shteynberg, M. M.; Ponomareva, T. N.; Schastlivtsev, V. M.: Influence of cooling rate on the position of martensitic transformation points. 1. Carbon steels. Phys. Met. Metallogr. 47 (1979) 1, pp. 102-111

60. Mirzayev, D. A.; Shteynberg, M. M.; Ponomareva, T. N.; Schastlivtsev, V. M.: Influence of cooling rate on the position of martensitic transformation points. 2. Alloyed steels. Phys. Met. Metallogr. 47 (1979) 5, pp. 73-79
61. Wilson, E. A.: $\gamma \rightarrow \alpha$ transformation in $\mathrm{Fe}, \mathrm{Fe}-\mathrm{Ni}$, and Fe-Cr alloys. Met. Sci. 18 (1984) 10, pp. 471-484, DOI:10.1179/030634584790253155

62. Huizing, R.; Klostermann, J. A.: The Martensite Transformation in Small (0.1-0.3 Mm) Iron-Nickel Single Crystals. Acta Metall. 14 (1966) 12, pp. 1693-1702, DOI:10.1016/0001-6160(66)90022-8

63. Kakeshita, T.; Saburi, T.; Kindo, K.; Endo, S.: Martensitic Transformations in Some Ferrous and Non-Ferrous Alloys under Magnetic Field and Hydrostatic Pressure. Phase Transitions 70 (1999) 2, pp. 65-113, DOI:10.1080/01411599908240678

64. Kakeshita, T.; Kuroiwa, K.; Shimizu, K.; Ikeda, T.; Yamagishi, A.; Date, M.: A new model explainable of both the athermal and isothermal natures of the martensitic transformations in Fe-Ni-Mn alloys. Mater. Trans. JIM 34 (1993) 5, pp. 423-428, DOI:10.2320/matertrans1989.34.423

65. Yeo, R. B. G.: Growth of martensite in an Iron- $28.8 \%$ Ni alloy. ASM Trans. Quarterly 57 (1964) 1, pp. 48-61

66. Crussard, C.; Philibert, J.: Etude de la cinétique de la transformation martinsitique et de la stabilisation de l'austénite. Revue De Metallurgie 53 (1956) 12, pp. 973980, DOI:10.1051/metal/195653120973

67. Raghavan, V.; Cohen, M.: Measurement and Interpretation of Isothermal Martensitic Kinetics. Metall. Trans. 2 (1971) 9, pp. 2409-2418, DOI:10.1007/bf02814878

68. Collins, D. N.; Dormer, J.: Deep cryogenic treatment of a D2 cold-work tool steel. Heat treat. of Metals 3 (1997), pp. 71-74

69. Das, D.; Dutta, A. K.; Ray, K. K.: Influence of varied cryotreatment on the wear behavior of AISI D2 steel. Wear 266 (2009) 1-2, pp. 297-309, DOI:10.1016/ j.wear.2008.07.001

70. Farina, P. F. d. S.; Barbosa, C. A.; Goldenstein, H.: Microstructural Characterization of an AISI D2 Tool Steel Submitted to Cryogenic Treatment ASTM Int. J. (2011) 5, pp. 1-8

71. Villa, M.; Christiansen, T.L.; Hansen, M. F.; Somers, M. A. J.: Sub-zero Celsius treatment: a promising option for future martensitic stainless steels. Proc. of the $23^{\text {th }}$ IFHTSE Congress, 18.-21.04.16, Savannah, USA, ASM Int., Curran Associates, Red Hook, NY, 2016, pp 317-325. - ISBN: 9781510823709

\section{Bibliography}

DOI:10.3139/105.110420

HTM J. Heat Treatm. Mat.

75 (2020) 5; page 263-286

(c) Carl Hanser Verlag GmbH \& Co. KG

ISSN 1867-2493 